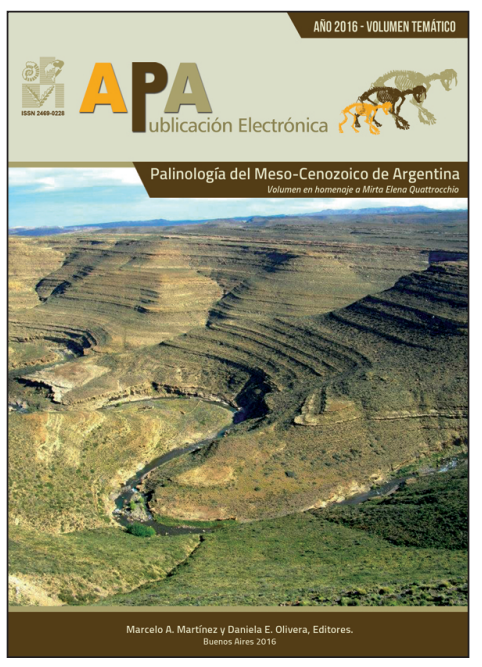

\title{
LATE CENOZOIC VERTEBRATES FROM THE SOUTHERNPAMPEAN REGION: SYSTEMATIC AND BIO-CHRONOSTRATIGRAPHIC UPDATE
}

CECILIA M. DESCHAMPS 1

RODRIGO L. TOMASSINI2

${ }^{1}$ Comisión de Investigaciones Científicas (CIC), División Paleontología Vertebrados, Museo de La Plata, Universidad Nacional de La Plata, La Plata, Argentina. ${ }^{2}$ Instituto Geológico del Sur (INGEOSUR)-Consejo Nacional de Investigaciones Científicas y Técnicas, Departamento de Geología, Universidad Nacional del Sur, Bahía Blanca, Argentina.

Recibido: 30 de marzo de 2016 - Aceptado: 6 de mayo de 2016

Para citar este artículo: Cecilia M. Deschamps and Rodrigo L. Tomassini (2016). Late Cenozoic vertebrates from the southern Pampean Region: systematic and bio-chronostratigraphic update. En: M. Martínez y D. Olivera (Eds.), Palinología del Meso-Cenozoico de Argentina - Volumen en homenaje a Mirta Elena Quattrocchio. Publicación Electrónica de la Asociación Paleontológica Argentina 16 (2): 202-225.

Link a este artículo: http://dx.doi.org/10.5710/PEAPA.06.05.2016.113

DESPLAZARSE HACIA ABAJO PARA ACCEDER AL ARTÍCULO

Asociación Paleontológica Argentina Maipú $6451^{\circ}$ piso, C1006ACG, Buenos Aires República Argentina Tel/Fax (54-11) 4326-7563 Web: www.apaleontologica.org.ar

Otros artículos en Publicación Electrónica de la APA 16(2):

\section{Borel, Guler, Navarro \& Astini}

ANCIENT COASTAL

ENVIRONMENTS IN A

MAASTRICHTIAN - ?PALEOCENE

ATLANTIC SHORELINE: A

PHYTOPLANKTON APPROACH

\section{Candel \& Borromei}

REVIEW OF THE PALAEOENVIRONMENTAL RECONSTRUCTION OF LATE QUATERNARY MARINE SEQUENCES, TIERRA DEL FUEGO (ARGENTINA)
Guler, Paolillo \& Martz

EARLY CRETACEOUS DINOFLAGELLATE CYSTS FROM THE NEUQUÉN AND AUSTRAL BASINS: A REVIEW 


\title{
LATE CENOZOIC VERTEBRATES FROM THE SOUTHERN PAMPEAN REGION: SYSTEMATIC AND BIO-CHRONOSTRATIGRAPHIC UPDATE
}

\author{
CECILIA M. DESCHAMPS ${ }^{1}$ AND RODRIGO L. TOMASSINI²
}

${ }^{1}$ Comisión de Investigaciones Científicas (CIC), División Paleontología Vertebrados, Museo de La Plata, Universidad Nacional de La Plata, La Plata, Argentina. ceci@fcnym.unlp.edu.ar

${ }^{2}$ Instituto Geológico del Sur (INGEOSUR)-Consejo Nacional de Investigaciones Científicas y Técnicas, Departamento de Geología, Universidad Nacional del Sur, Bahía Blanca, Argentina. rodrigo.tomassini@yahoo.com.ar

\begin{abstract}
The knowledge of the vertebrate systematics and bio-chronostratigraphy of Late Cenozoic from the southwest of the Buenos Aires Province is updated. The study is focused on 12 localities that encompass the latest Miocene to the Holocene. Biostratigraphic units were identified and correlated to those of other areas of the Pampean Region. Farola Monte Hermoso, Bajo San José and Playa del Barco outstand because they yielded a large amount of fossil remains. In turn, the quarries near Grünbein allowed refining the age of "Huayquerian" faunas and their relationship with "Montehermosan" ones. The localities Cantera Seminario, Barrancas de Sarmiento, Cantera Vialidad, and Cantera Relleno Sanitario are assigned to the latest Miocene-earliest Pliocene; Farola Monte Hermoso and Las Oscuras, to the Early Pliocene; Bajo San José to the Middle Pleistocene; Puesto La Florida, Chacra Santo Domingo, and García del Río to the Late Pleistocene-Holocene; Playa del Barco to the Late Pleistocene; Pliocene s.l, and Pleistocene-Holocene levels are exposed at Balneario Saldungaray.
\end{abstract}

Key words. Biostratigraphy. Mammals. Late Miocene-Holocene. Buenos Aires Province. Argentina.

Resumen. VERTEBRADOS DEL CENOZOICO TARDÍO DEL SUDOESTE DE LA REGIÓN PAMPEANA: ACTUALIZACIÓN SISTEMÁTICA Y BIOCRONOESTRATIGRÁFICA. Se realiza una actualización del conocimiento de la sistemática de los vertebrados y la bio-cronoestratigrafía del Cenozoico tardío del sudoeste de la Provincia de Buenos Aires. El trabajo se enfoca en 12 localidades que abarcan desde el Mioceno más tardío hasta el Holoceno. En ellas se identificaron unidades bioestratigráficas que se correlacionan con otras áreas de la Región Pampeana. Se destacan Farola Monte Hermoso, Bajo San José y Playa del Barco como las localidades más fosilíferas. Por su parte, las canteras cercanas a la localidad de Grünbein se destacan por permitir la aproximación a las edades de faunas "huayquerienses" y su relación con las "montehermosenses". Las localidades Cantera Seminario, Barrancas de Sarmiento, Cantera Vialidad y Cantera Relleno Sanitario se asignan al Mioceno más tardío-Plioceno más temprano; Farola Monte Hermoso y Las Oscuras al Plioceno Temprano; Bajo San José al Pleistoceno Medio; Puesto La Florida, Chacra Santo Domingo y García del Río al Pleistoceno Tardío-Holoceno; Playa del Barco al Pleistoceno Tardío; en Balneario Saldungaray afloran niveles asignados al Plioceno s.l. y al Pleistoceno-Holoceno.

Palabras clave. Bioestratigrafía. Mamíferos. Mioceno Tardío-Holoceno. Provincia de Buenos Aires. Argentina.

THE TEMPoral scheme of the South American Cenozoic was established in the XIX Century by Ameghino (e.g., Ameghino, 1889,1898 ) on the basis of mammal assemblages of Patagonia and central Argentina. Pascual et al. (1965) introduced the first scheme of South American land-mammal ages (SALMAs), following the proposal of Ameghino, which was not substantially modified. The temporal calibration of the continental Late Miocene-Holocene is based mostly on mammal faunas from central Argentina. This interval includes the Chasicoan, Huayquerian, Montehermosan, Cha- padmalalan, Marplatan, Ensenadan, Bonaerian, Lujanian and Platan SALMAs and Stages/Ages (Cione and Tonni, 1995, and references therein).

The southwestern Buenos Aires Province represents an outstanding area to study the biochronology and biostratigraphy of this interval based on the analysis of mammals because it has several outcrops bearing remains of at least the last $10 \mathrm{My}$. Some of them were already well known in the paleontological literature, for example Farola Monte Hermoso (Darwin, 1846; Bravard, 1857; Ameghino, 1887, 
1889; Frenguelli, 1928, 1950; J.L. Kraglievich, 1946; Leanza, 1948; Bonaparte, 1960; more recently Tonni et al., 1992, among others), Punta Alta (Darwin, 1846), Playa del Barco (Ameghino, 1908; L. Kraglievich, 1926, 1934; Frenguelli, 1928; Cabrera, 1929; J.L. Kraglievich, 1946; Parodi Bustos, 1962; more recently Aramayo and Manera de Bianco, 1989; Tomassini et al., 2010). However, the idea to undertake investigations with a multidisciplinary approach began in the 1980s with the initiative of Dr. Mirta Quattrocchio by forming a team to conduct geo-paleontological researches.

The Laboratory of Palynology of the Universidad Nacional del Sur headed by Dr. Quattrocchio was already well known for the palynological studies in Argentina and abroad. By those times the staff began to study the profiles exposed along rivers, creeks, roads and railways cuts in the area of Bahía Blanca in which Late Cenozoic sediments were represented. We joined the field work together with palynologists, sedimentologists and specialists in microinvertebrates that were already part of the team, with the aim of

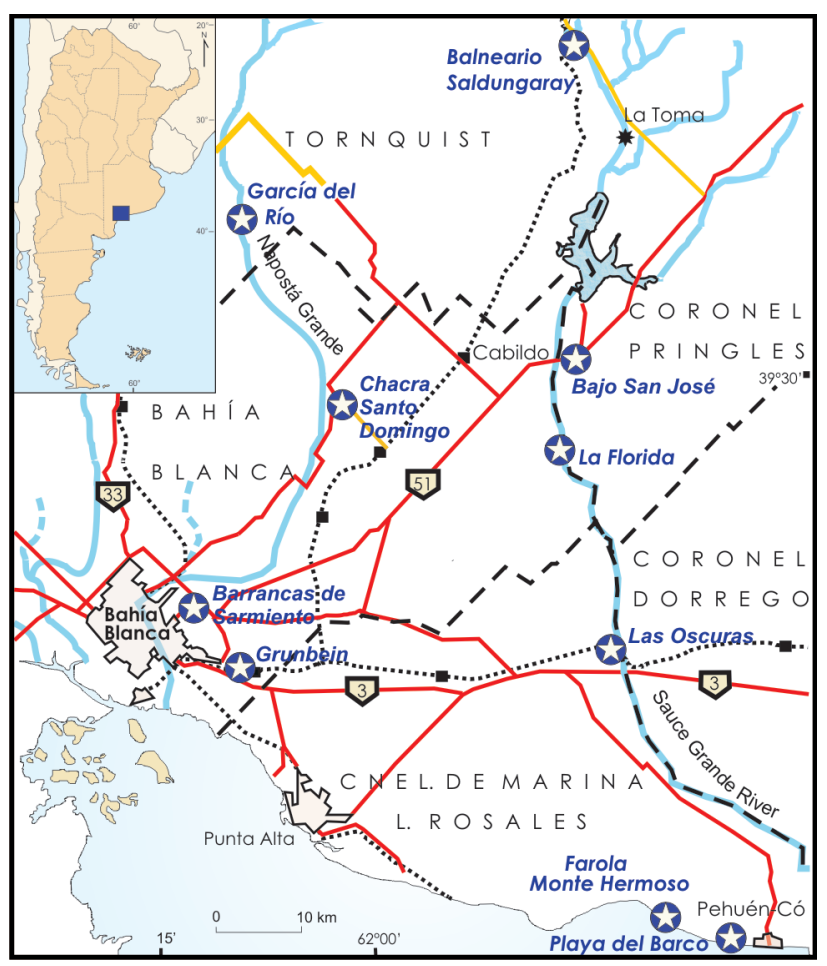

Figure 1. Location map showing the studied localities. Grünbein represents three quarries very close to each other: canteras Seminario, Vialidad and Relleno Sanitario. making our contribution from the point of view of vertebrate paleontology. The common idea was to make the reconstruction of the geological and paleoenvironmental evolution of the area.

During field work, several exposures appropriate for multidisciplinary study were found. In some of them the vertebrate record was scarce, but anyway they were significant when making the correlation with other localities. In this way, a wider span of time and geographic area could be studied.

The first results were limited to specific localities (e.g., Quattrocchio et al., 1988; Deschamps and Borromei, 1992; Deschamps and Tonni, 1992; Verzi and Deschamps, 1996; Deschamps et al., 1998), but with time, data were used to make bio-chronostratigraphic proposals (Deschamps, 2003, 2005), which were refined in subsequent papers (e.g., Verzi et al., 2004a, 2008; Deschamps et al., 2012, 2013; Tomassini, 2012; Tomassini and Montalvo, 2013; Tomassini et al., 2013a) even making inferences about environmental conditions suggested by the recorded taxa. In this sense, rodents were particularly important among mammals (Verzi et al., 2004a; Quattrocchio et al., 2008; Deschamps et al., 2009, 2012, 2013; Tomassini et al., 2013a; Vucetich et al., 2014a,b, 2015).

The purpose of the present contribution is to provide an update of both the stratigraphic proposal, and the mammal systematics on which it is based, for the Late MioceneHolocene interval, within an area of the southwest of the Buenos Aires Province between $38^{\circ} 20^{\prime}-39^{\circ} \mathrm{S}$, and $61^{\circ}$ $35^{\prime}-62^{\circ} 10^{\prime} \mathrm{W}$ (Fig. 1). In this way, we wish to acknowledge Dr. Mirta Quattrocchio and to offer this work as a tribute for the influence she has had on the development of our careers.

\section{GEOLOGICAL SETTING}

The oldest sediments bearing vertebrate remains in this area correspond to the Late Miocene interval and form the regional substrate above which the present relief was elaborated (Zárate, 2005). These are massive to coarsely stratified, brownish red to yellowish sandy silts ending with a massive carbonate level, known as "Pampean sediments". The exposures are generally isolated along the banks of drainage systems. Different lithostratigraphic units were named for these sediments (some of them without the re- 
quirements of the stratigraphic Argentinean code CAE, 1992), e.g., Arroyo Chasicó (Pascual, 1961), Epecuén (Pascual, 1961), Pampiano (Fidalgo et al., 1973), La Norma (De Francesco, 1992), Irene (Reig, 1955), Saldungaray and La Toma (Furque, 1967) formations. Folguera and Zárate (2009, 2011) gathered them as the Cerro Azul Formation and interpreted that they represent distal sinorogenic facies that document the Andean tectonic dynamic. Folguera and Zárate (2009) and Montalvo et al. (2012) proposed an evolutionary, regional geological model to explain the geographical distribution and antiquity of the faunal emblages found in the Cerro Azul Formation (see Verzi, 1999). According to the fossil content it includes deposits of the Chasicoan and Huayquerian ages (Fig. 2). The accumulation of these sediments began after the regression of the Paranense sea, identified in northeastern Argentina as Paraná and Entre Ríos formations (sensu Chebli et al., 1999), and Barranca Final Formation in northeastern Patagonia (Colorado Basin; Zambrano, 1972). The establishment of these diverse groups of environments that favored the development of continental vertebrates was called Edad de las Planicies Australes (the age of the austral plains) by Pascual and Bondesio (1982). According to Zárate (2005) there was a progressive trend towards cooling and aridization, with alternating wetter and warmer conditions. In most sections sedimentation was related to fluvial agents or water bodies; eolian facies were subordinated, although through time they became dominant.

Pliocene sediments were grouped together with those Late Miocene ones as the "Araucanense". They include the Montehermosan and Chapadmalalan ages. Several exposures, mainly represented by cliffs located in the Atlantic coast, yielded abundant mammal remains, being the most significant those of Farola Monte Hermoso and the area of Mar del Plata-Miramar, which are mostly related to fluvial environments.

The sedimentary record of the latest Pliocene-Pleistocene is represented by fluvial and aeolian sequences which are subject of several stratigraphic proposals in different areas of the Buenos Aires Province (see Zárate, 2005). Landscape reactivation occurs with the development of valleys carved in the Mio-Pliocene substrate. The fluvial Late PleistoceneHolocene units are the equivalents to the Luján Formation of northeastern Buenos Aires Province (Fidalgo et al., 1973): Agua Blanca Formation (De Francesco, 1992, and modifications of Rabassa, 1989, and Zavala and Quattrocchio, 2001) or part of the San José Sequence and Agua Blanca Sequence (Zavala and Quattrocchio, 2001), as well as the Chacra La Blanqueada Formation (Rabassa, 1989), the youngest fluvial unit, corresponding to overflow sediments. The eolian sediments of this interval are included in the Saavedra Formation (De Francesco, 1992), equivalent to the La Postrera Formation of eastern Buenos Aires Province (Fidalgo et al., 1973), and Matadero Saldungaray Formation (Rabassa, 1989), which represents the youngest eolian sediments of historical times.

Zavala and Quattrocchio (2001) produced a chronostratigraphic chart in which they proposed the relationships

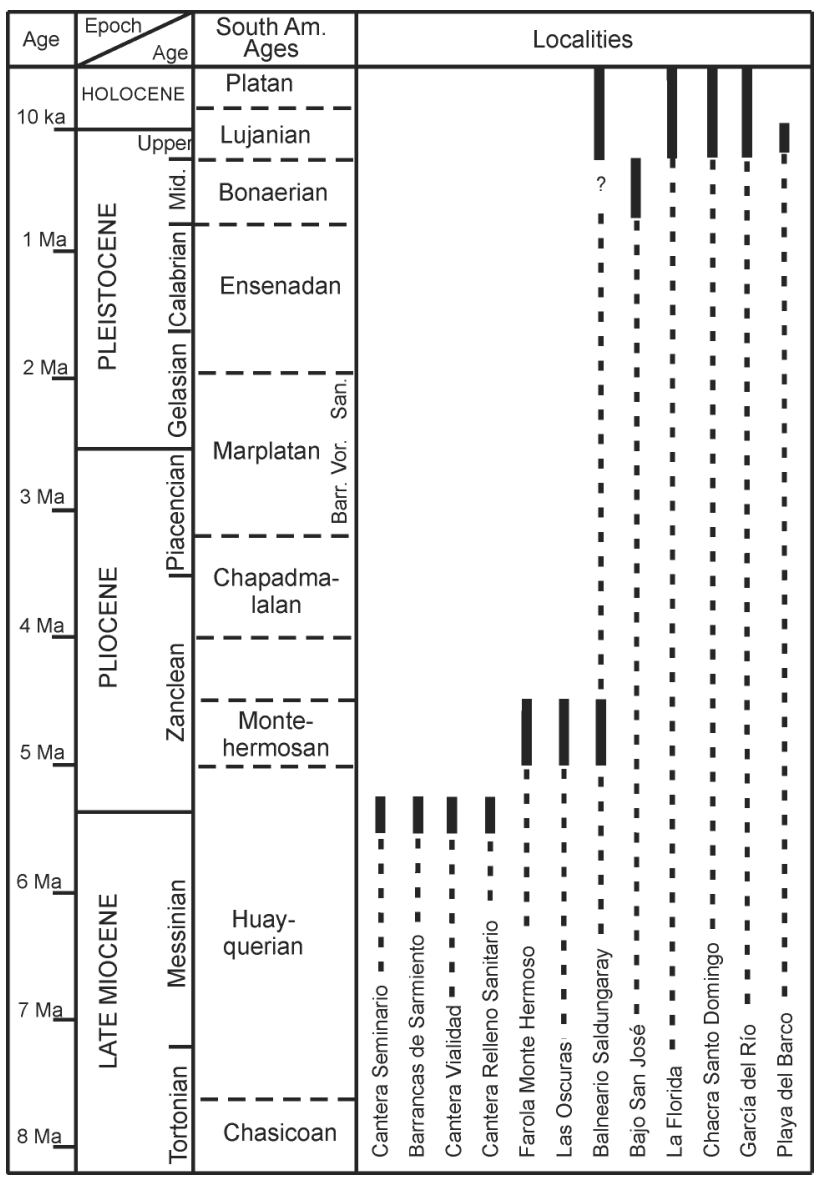

Figure 2. Stratigraphic chart showing the levels exposed at the studied localities correlated with International and South American ages. 
among the lithostratigraphic units of the Late Cenozoic. The finding of mammals in many of them (Verzi et al., 2004a, 2008; Deschamps, 2005; Tomassini et al., 2010, 2013a; Deschamps et al., 2012, 2013) together with numerical ages (e.g., Aramayo, 1997; Schultz et al., 2006) allowed improving their temporal assignment.

\section{STUDIED LOCALITIES}

The localities representing the Late Miocene-Holocene interval selected for this contribution will be listed according to the age of the exposed sediments from oldest to youngest. See complete list of taxa in Appendix 1.

\section{Late Miocene-Pliocene}

This interval was studied in quarries near Bahía Blanca and cliffs of the Sauce Grande River and the Atlantic coast. 1) Cantera Seminario

Location: $38^{\circ} 44^{\prime} 08^{\prime \prime} \mathrm{S}, 62^{\circ} 12^{\prime} 19^{\prime \prime} \mathrm{W}$; 58-68 m height (see Grünbein in Figs. 1, 3.1).

Bearing unit: Cerro Azul Formation (sensu Folguera and Zárate, 2009). The section is $11 \mathrm{~m}$ thick and was divided into five levels. Fossils were found in the upper part of level 2 , below the calcrete crust.

Biostratigraphic units recognized in the sequence: type section of the Xenodontomys ellipticus Zone (Verzi et al., 2008).

Age: Late Huayquerian (Late Miocene-earliest Pliocene; late Messinian-early Zanclean; see below; Deschamps et al., 2013).

Fossil content: the octodontid rodents Xenodontomys ellipticus and Phtoramys cf. P. hidalguense are important biostratigraphic indicators (see Deschamps et al., 1998; Deschamps, 2005; Verzi et al., 2008 for details). Other taxa include: Doellotatus cf. D. inornatus, D. cf. D. praecursor, Chorobates sp., Paedotherium cf. P. minor, Tremacyllus cf. T. impressus, Orthomyctera sp., cf. Palaeocavia) and Lagostomus sp. (we follow Rasia, 2016 for the validity of "Lagostomopsis") (Fig. 4).

2) Barrancas de Sarmiento

Location: $38^{\circ} 42^{\prime} 05^{\prime \prime} \mathrm{S}, 62^{\circ} 15^{\prime} 51^{\prime \prime} \mathrm{W} ; 50 \mathrm{~m}$ height (Figs. 1, 3.2).

Bearing unit: Cerro Azul Formation (sensu Folguera and Zárate, 2009).

Biostratigraphic units recognized in the sequence: Xenodontomys ellipticus Zone (Verzi et al., 2008).
Age: Late Huayquerian (Late Miocene-earliest Pliocene; late Messinian-early Zanclean; see below; Deschamps et al., 2013).

Fossil content: Xenodontomys ellipticus is an important biostratigraphic indicator (see Verzi and Deschamps, 1996; Deschamps, 2005; Verzi et al., 2008 for details). Other taxa: Paedotherium bonaerense, Lagostomus sp., ?Palaeocavia, and Eutatini indet. (Fig. 5)

3) Cantera Vialidad

Location: $38^{\circ} 45^{\prime} 19.89^{\prime \prime}$ S, 62 09' 39.75" W; 51-64 m height (see Grünbein in Fig. 1, 3.3).

Bearing unit: Cerro Azul Formation (sensu Folguera and Zárate, 2009).

Biostratigraphic units recognized in the sequence: Xenodontomys ellipticus Zone (Verzi et al., 2008).

Age: Late Huayquerian (Late Miocene-earliest Pliocene; late Messinian-early Zanclean; see below; Deschamps et al., 2013). This deposit has a numerical dating of 5.28 $\pm 0.04 \mathrm{Ma}$ (Schultz et al., 2006).

Fossil content: Xenodontomys ellipticus is an important biostratigraphic indicator which allows correlations with Barrancas de Sarmiento and Cantera Seminario. Remains of this rodent were found in the same level of the dating, and also in overlying levels (Deschamps et al., 2013; Deschamps and Tomassini, personal observations). Other unpublished taxa include Paedotherium sp., and Chorobates villosissimus.

4) Cantera Relleno Sanitario

Location: $38^{\circ} 46^{\prime} 24^{\prime \prime} \mathrm{S}, 62^{\circ} 09^{\prime} 25^{\prime \prime} \mathrm{W}$; 12-24 m height (see Grünbein in Figs. 1, 3.4.)

Bearing unit: Cerro Azul Formation (sensu Folguera and Zárate, 2009). This section has $8 \mathrm{~m}$ mean thickness divided into five levels on the basis of calcrete crusts and paleosoils. Materials were recovered from two levels at the middle of the exposure.

Biostratigraphic units recognized in the sequence: Xenodontomys ellipticus Zone (Verzi et al., 2008) because of the presence of Phtoramys cf. P. hidalguense.

Age: Late Huayquerian (Late Miocene-earliest Pliocene; late Messinian-early Zanclean; see below; Deschamps et al., 2013).

Fossil content: From the lower Level 1 (paleosoil): cf. Borhyaenidium Phtoramys cf. P. hidalguense, Macrochorobates sp., Promacrauchenia sp.; Level 2 (calcrete level overlying the pa- 
leosoil): Chasicotatus cf. C. peiranoi, Chorobates villosissimus, Macroeuphractus cf. M. morenoi, cf. Aspidocalyptus, cf.
Berthawyleria, Paedotherium cf. P. minor, Tremacyllus cf. T. impresus, and Promacrauchenia sp. (Fig. 6).

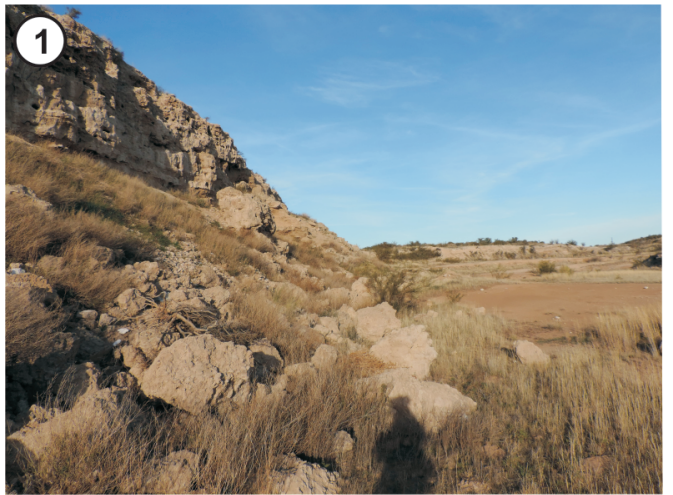

(4)
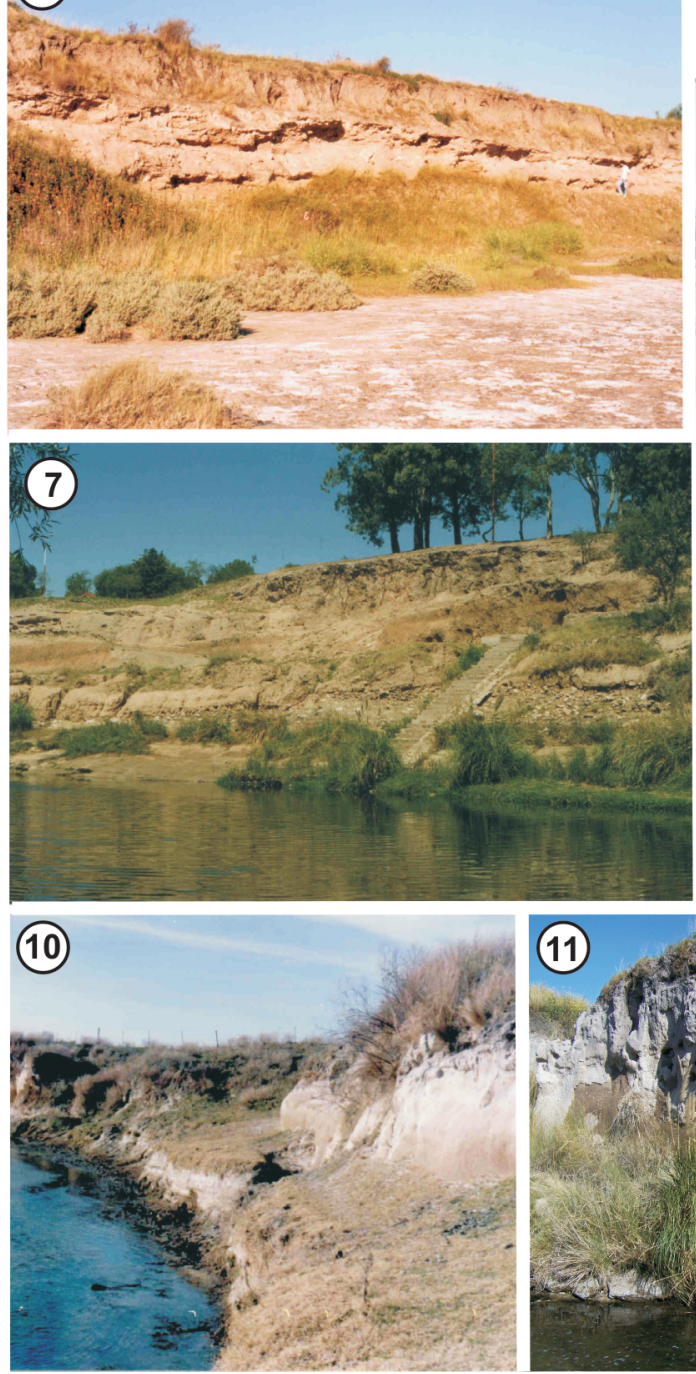

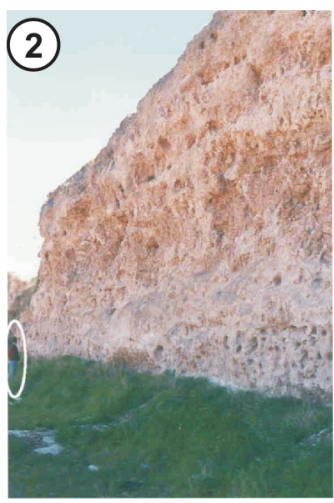

(5)
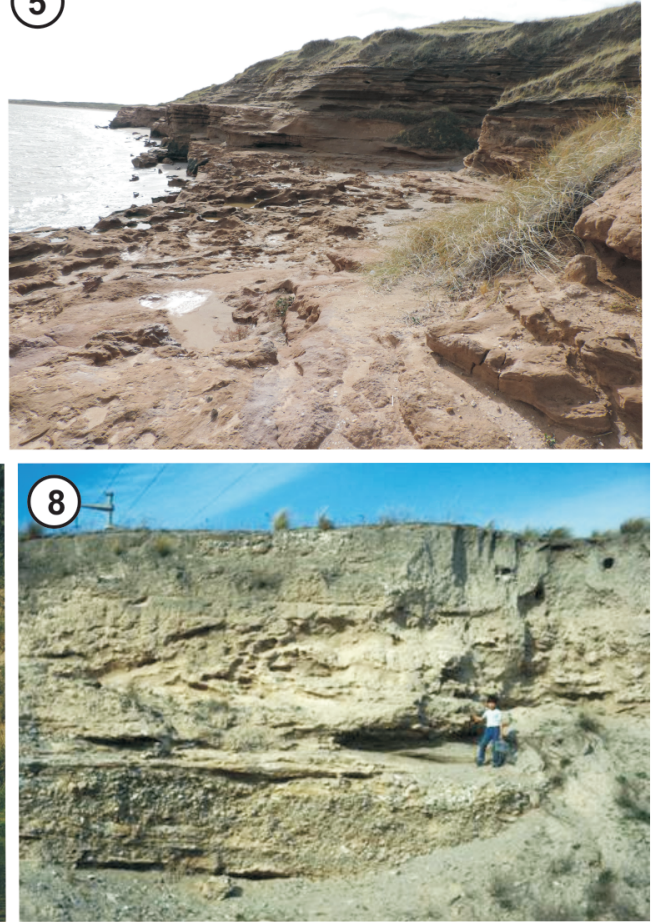

(3)

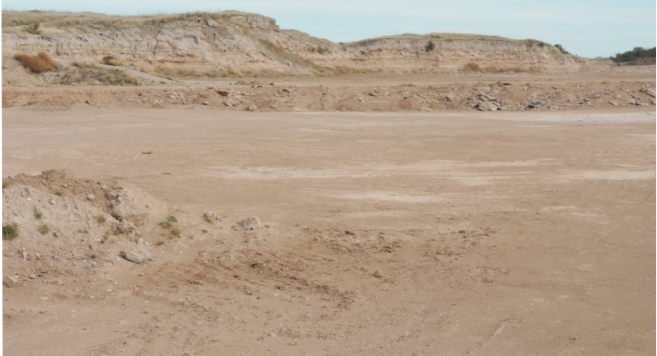

(6)
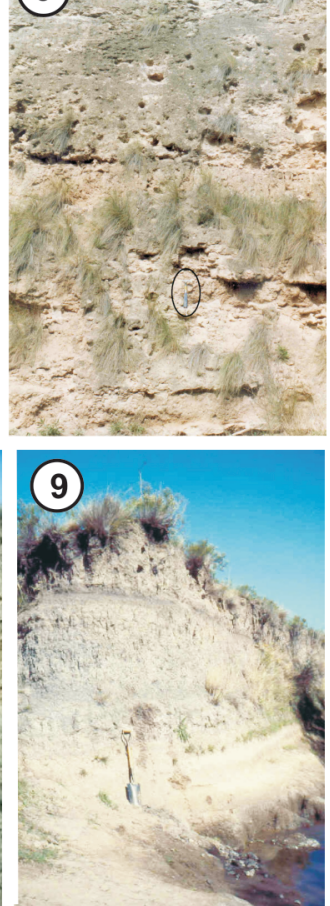

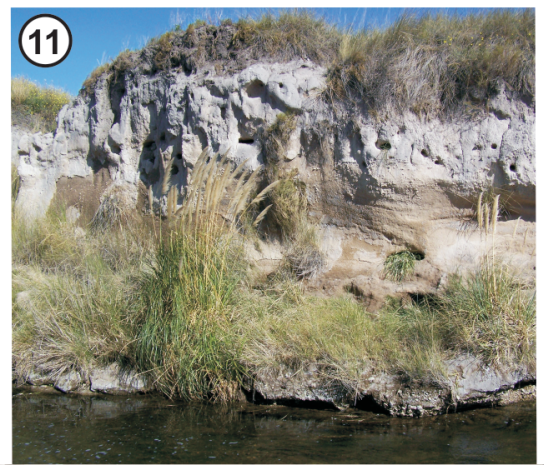

(12)

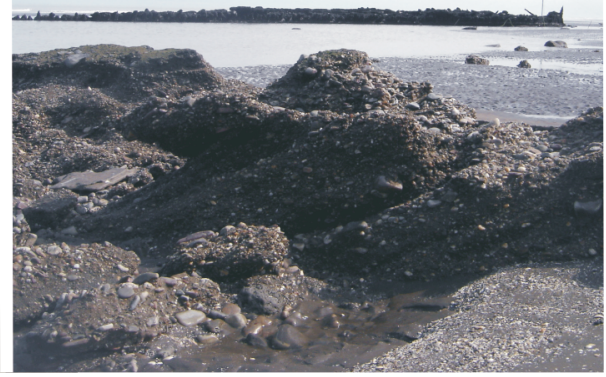

Figure 3. View of the exposures at the studied localities. 1, Cantera Seminario; 2, Barrancas de Sarmiento; 3, Cantera Vialidad; 4, Cantera ReIleno Sanitario; 5, Farola Monte Hermoso; 6, Las Oscuras; 7, Balneario Saldungaray; 8, Bajo San José; 9, Puesto La Florida; 10, Chacra Santo Domingo; 11, García del Río; 12, Playa del Barco. 


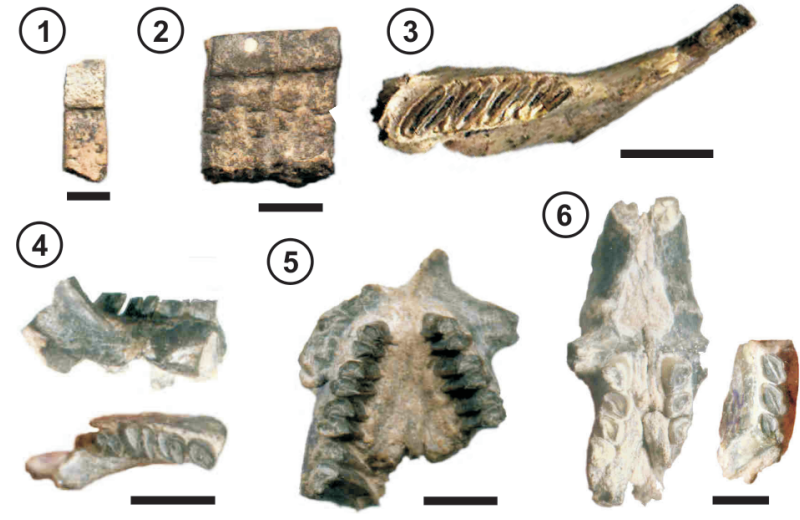

Figure 4. Mammals found in Cantera Seminario. 1, osteoderm of Doellotatus cf. D. inornatus; 2, two osteoderms of Doellotatus cf. $D$. praecursor; 3, fragment of left mandible of Lagostomus sp.; 4, fragment of right mandible of Phtoramys cf. P. hidalguense; 5, skull fragment of Orthomyctera sp.; 6 , skull and left mandible fragments of Xenodontomys ellipticus. Anterior to the right $(3,4)$ and to top $(5,6)$. Scale $=1 \mathrm{~cm} \mathrm{(1,2),} 5 \mathrm{~cm}(3), 5 \mathrm{~mm}(4-6)$.

5) Farola Monte Hermoso

Location: 38 58' 01" S, 614 41' 43" W; 0-10 m height (Figs. 1, 3.5).

Bearing unit: Monte Hermoso Formation (Zavala, 1993).

Biostratigraphic units recognized in the sequence: type section of the Eumysops laeviplicatus Range Zone (Tomassini et al., 2013a).

Age: Montehermosan (Early Pliocene; Zanclean; Tomassini et al., 2013a).

Fossil content: Eumysops laeviplicatus, Eumysops formosus, Eucelophorus cabrerai, Pithanotomys columnaris, Phugatherium cataclisticum are important biostratigraphic indicators (Deschamps et al., 2012, 2013; Tomassini et al., 2013a). Other frequent taxa include Actenomys priscus, Paramyocastor diligens (see Verzi et al., 2002), Paedotherium bonaerense, Paedotherium typicum, Tremacyllus impressus, Doellotatus inornatus, Eoauchenia primitiva, Pseudotypotherium sp. and Plohophorus figuratus (Fig. 7). See complete list in Appendix 1.

Recently, the knowledge of this fauna has been greatly increased with systematic, taphonomic, paleoenvironmental and paleobiogeographic contributions (e.g., Zurita and Tomassini, 2006; Albino et al., 2009; Tomassini and Montalvo, 2010, 2013; Miño-Boilini et al., 2011; Tomassini et al., 2011, 2014a; Agnolin and Tomassini, 2012; Agnolin et al., 2014).
(1)

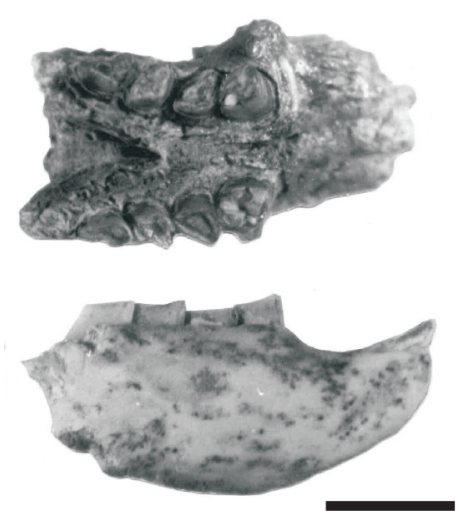

(2)

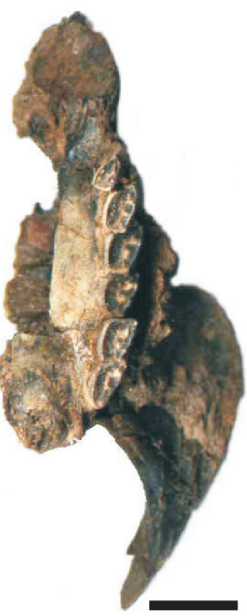

Figure 5. Mammals found in Barrancas de Sarmiento. 1, skull fragment and right mandible of Xenodontomys ellipticus; 2, skull fragment of Paedotherium bonaerense. Anterior to the right (1) and to top (2). Scales= $4 \mathrm{~mm}(1)$ and $1 \mathrm{~cm} \mathrm{(2).}$
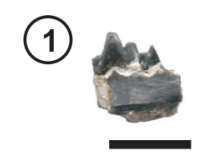

(4)

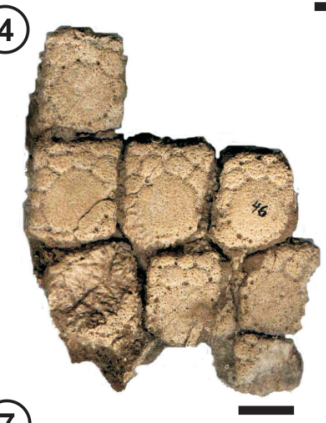

(2)

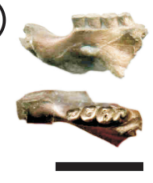

(3)

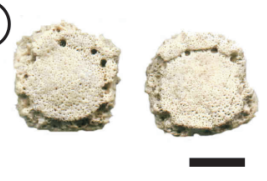

(7)

\section{(5)}

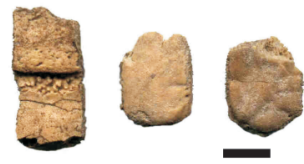

(6)
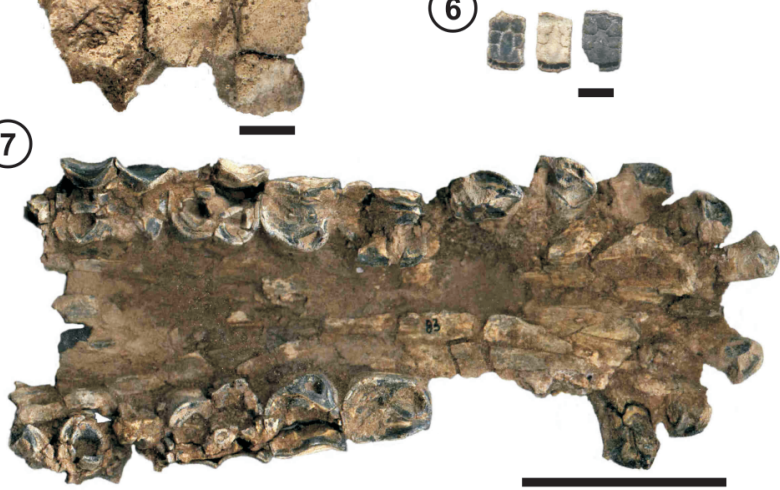

Figure 6. Some of the specimens found in Cantera Relleno Sanitario. 1, mandible fragment of cf. Borhyaenidium; 2, mandible fragment of Phtoramys cf. P. hidalguense; 3, osteoderms of Aspidocalyptus sp.; 4, carapace fragment of cf. Berthawyleria; 5, osteoderms of Macroeuphractus cf. M. morenoi; 6, osteoderms of Chasicotatus sp.; 7, palate fragment of Promacrauchenia sp. Anterior to left (2) and to the right (7). Scales $=1 \mathrm{~cm}(1-6), 5 \mathrm{~cm}$ (7). 
(1)

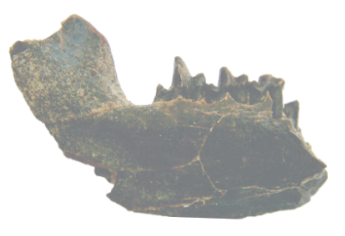

(4)

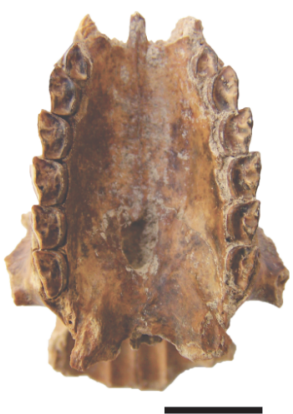

(5)
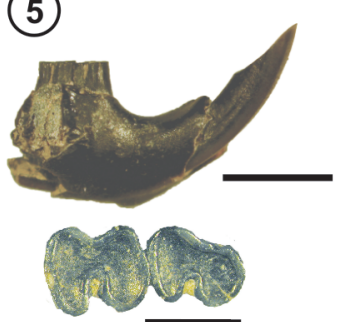

(7)

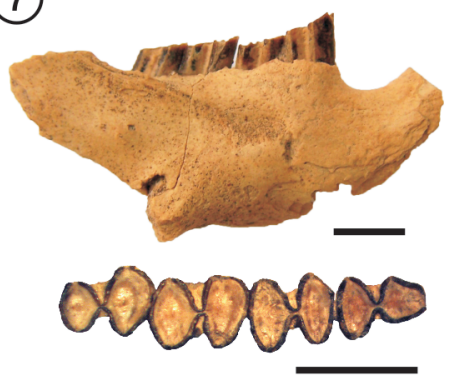

(10)

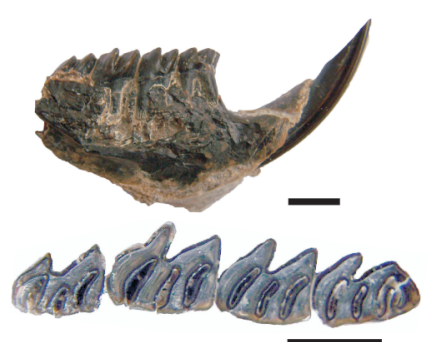

(2)

(6)

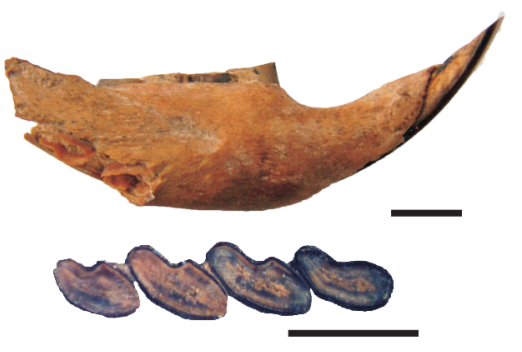

(8)

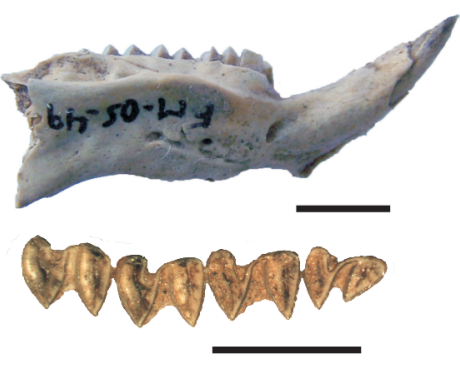

(3)

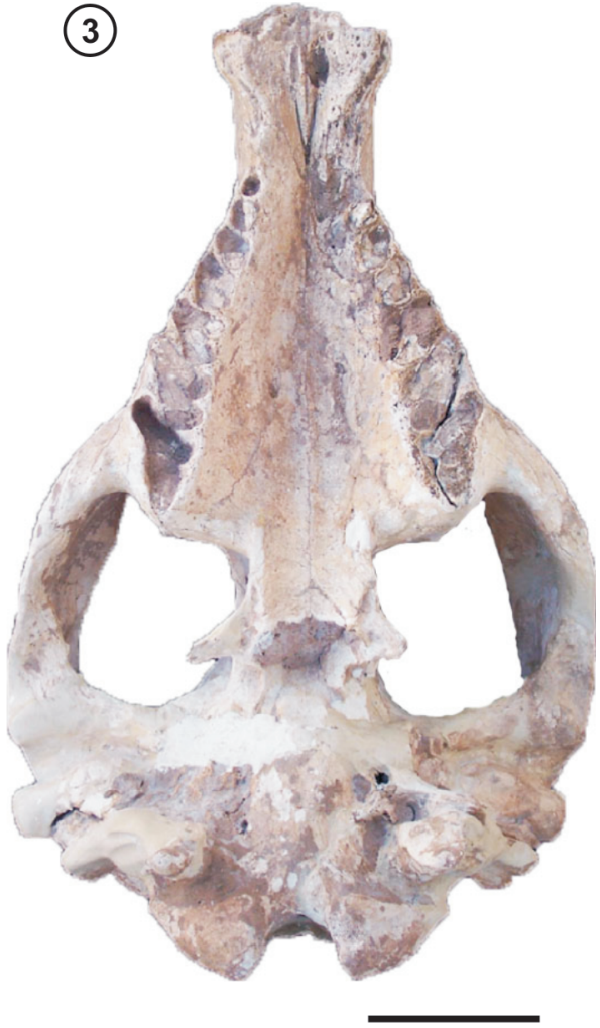

(9)

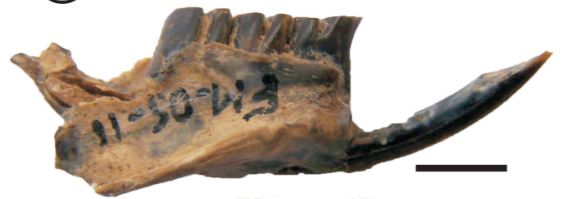

angusige

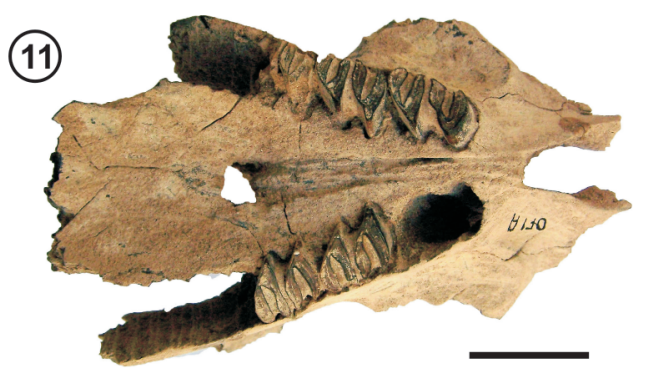

Figure 7. Some of the mammals found in Farola Monte Hermoso. 1, left mandible fragment of Hyperdidelphys inexpectata (inverted); 2, skull fragment in ventral view of Pseudotypotherium sp.; 3, skull in ventral view of Toxodon chapalmalensis; 4, skull fragment in ventral view of Paedotherium bonaerense; 5-9, right mandible fragments and detail of dental series in occlusal view of: 5, Neophanomys sp.; 6, Actenomys priscus; 7, Pithanotomys columnaris; 8, Palaeocavia sp.; 9, Eumysops laeviplicatus; 10, left mandible fragment and detail of dental series in occlusal view (inverted) of Paramyocastor diligens; 11, skull fragment of Phugatherium cataclisticum. Anterior to right (1, 5-11) and to top (2-4). Scales= $5 \mathrm{~mm}(A, E-J), 1 \mathrm{~cm}(B, D), 10 \mathrm{~cm}(C)$, and $2 \mathrm{~cm}(K)$. 
According to Tomassini et al. (2013a) this biostratigraphic unit represents a brief lapse, included within a temporal range whose approximate boundaries are $<5.28 \mathrm{Ma}$ and 4.5/5.0 Ma.

6) Las Oscuras

Location: $38^{\circ} 44^{\prime} 48.55^{\prime \prime} \mathrm{S}, 61^{\circ} 44^{\prime} 01.04^{\prime \prime} \mathrm{W} ; 82 \mathrm{~m}$ height (Fig. 1, 3.6).

Bearing unit: Saldungaray-La Toma formations (sensu Deschamps, 2005); Cerro Azul Formation (sensu Folguera and Zárate, 2009).

Biostratigraphic units recognized in the sequence: Actenomys priscus-Plohophorus cuneiformis Zone (Deschamps, 2005). This unit may correspond to the Eumysops laeviplicatus Range Zone defined in Farola Monte Hermoso (see discussion in Tomassini et al., 2013a).

Age: Montehermosan (Early Pliocene; Zanclean; sensu Deschamps, 2005).

Fossil content: Actenomys priscus, Plohophorus cuneiformis, Pseudotypotherium sp., Lagostomus sp., Orthomyctera sp., Dolicavia sp., and Epitherium laternarium (Deschamps et al., 1989; Deschamps, 2005).

The record of Actenomys priscus, with similar characteristics to the specimens recovered from Farola Monte Hermoso, plus the absence of the different species of Xenodontomys, support the proposed age.

\section{Pleistocene-Holocene}

This interval was studied in the banks of the Sauce Grande River and Napostá Grande Creek.

7) Sauce Grande River valley

a-Balneario Saldungaray

Location: $38^{\circ} 11^{\prime} 52.30^{\prime \prime} \mathrm{S}, 61^{\circ} 46^{\prime} 11.39^{\prime \prime}$ W; 20 m height (Figs. 1, 3.7).

Bearing unit: The sequence begins with deposits of the Saldungaray Formation at the water level. This unit is overlain by coarse conglomerates and sands of the lower and upper sections of the San José Sequence (Zavala and Quattrocchio, 2001). Rabassa (1989) assigned these two latter units to the Agua Blanca Formation on the basis of two radiocarbon datings (32,300 +/- 1,800 RCYBP; Figini et al., 1989; 27,500 +/- 670 RCYBP; Figini et al., 1989; Rabassa, 1989) but geomorphology and stratigraphic position suggest an older age for these units. The profile ends with eolian deposits of the
Matadero Saldungaray Formation.

Biostratigraphic units recognized in the sequence: The recorded taxa were insufficient to recognize any unit.

Age: Pliocene s.l. (Saldungaray Formation), Middle Pleistocene (San José Sequence according to Zavala and Quattrocchio, 2001 and Deschamps, 2005), or Late Pleistocene Agua Blanca Formation (according to Rabassa, 1989), Historical times-Present (Matadero Saldungaray Formation). Fossil content: Mammal remains were very scarce. Saldungaray Formation: Paedotherium bonaerense; San José Sequence, lower section: Glossotherium sp. and Lamasp.; upper section Lagostomus sp.; Matadero Saldungaray Formation: Ctenomys talarum and Lepus europaeus.

b-Bajo San José

Location: $38^{\circ} 29^{\prime} 12.10^{\prime \prime}$ S, 61 46' 59.60" W; 125 m height (Figs. 1, 3.8).

Bearing unit: San José Sequence (Zavala and Quattrocchio, 2001), especially a sandy lens up to $1 \mathrm{~m}$ thick of the lower section that yielded most of the small vertebrates, $2 \mathrm{~m}$ from the base of the profile.

Biostratigraphic units recognized in the sequence: type section of the Ctenomys kraglievichi Zone (Verzi et al., 2004a). The zone was also recognized at Las Grutas-Punta Negra in Necochea (southeastern Buenos Aires Province), as well as in Camet and Constitución, in the cliffs north of Mar del Plata.

Age: Bonaerian (Middle Pleistocene; Verzi et al., 2004a) Fossil content: the ctenomyid rodent Ctenomys kraglievichi as well as the dasypodid Tolypeutes sp. nov. (Scillato-Yané in Deschamps, 2005) are important biostratigraphic indicators, exclusive of the Bonaerian. Other taxa include: Pisces ( $P i-$ melodella aff. P. laticeps, Callichthys callichthys, Percichthys sp., Corydoras cf. C. paleatus), turtles (Hydromedusa tectifera), birds (Rhea sp., Chloephaga sp. 1, Chloephaga sp. 2, Porphyrio sp., cf. Pseudoseisura cursor-Pseudoseisuropsis nehuen, Motacillinae indet.), marsupials (Lestodelphys sp.), dasypodids (Chaetophractus villosus, Zaedyus pichiy, Eutatus seguini, Propraopus sp.), glyptodontids (Glyptodon clavipes, Doedicurus sp., Panochthus tuberculatus, Sclerocalyptus cf. S. ornatus), sloths (Scelidotherium cf. S. leptocephalum, Glossotherium sp., Lestodon armatus, Megatherium americanum), litopterns (?Macraucheniopsis ensenadensis), notoungulates (Toxodon sp.), cricetid rodents (Akodon cf. A. azarae, Akodon cf. A. inisca- 
tus, Oxymycterus sp., Reithrodon auritus, Phyllotis sp., Lundomys sp.), caviomorph rodents (Microcavia sp., Galea sp., Lagostomus sp., Neochoerus cf. N. tarijensis, Myocastor columnaris), Gomphotheriidae indet., artiodactyls (Tayassuinae indet., Lama sp., Cervidae indet.), perissodactyls (Hippidion principale), and carnivores (Pseudalopex sp., cf. Herpailurus) (Fig. 8). See complete list in Appendix 1.

The oldest records of Callichthys callichthys, Percichthys, Porphyrio, Herpailurus, Lundomys, Oxymycterus, Phyllotis, and Tayassuinae (Cione and López Arbarello, 1995; Pardiñas and Deschamps, 1996; Prevosti, 2006; Pardiñas and Teta, 2011; Gasparini, 2013) come from this site.

Some taxa are significant from a biogeographic point of view. Among Osteichthyes, the pimelodid siluriformes Pimelodella, Callichthys and Corydoras, and the Percichthydae Percichthys are not simpatric today. The southern border of the geographic distribution of Callichthys is currently farther north within the Buenos Aires Province, and on the contrary, Percichthys inhabits today the Austral Subregion (Cione and López Arbarello, 1995). This is the southernmost record of the turtle Hydromedusa tectifera which today inhabits the Neotropical Region up to northern Argentina (de la Fuente, 1992, 1999).

As well, other taxa are important in view of their paleoenvironmental meaning (for details see Pardiñas and Deschamps, 1996; Deschamps, 1998; Deschamps et al., 2000; Verzi et al., 2004a; Deschamps, 2005; Prevosti, 2006; Pardiñas and Teta, 2011; Gasparini, 2013).

The birds record is outstanding because three orders are represented, Anseriformes, Gruiformes and Passeriformes (Tonni and Deschamps, 2001). Anseriformes, Family Anatidae, include several remains of small indeterminate anatids and Chloephaga. This genus would be represented by two new species. Gruiformes is represented by the Family Rallidae, genus Porphyrio. Passeriformes are recorded by a large furnariid similar to Pseudoseisura cursor and Pseudoseisuropsis nehuen (both from the Ensenadan of the Buenos Aires Province; Tonni and Noriega, 2001) and an indeterminate passeriid of the Family Motacillinae. Modern Pseudoseisura are widely distributed in South America inhabiting arid environments, but both species of Porphyrio inhabit intertropical South America. This means that Porphyrio would join Callichthys, Hydromedusa and Lundomys in warm and humid environments, and Chloephaga would join Percichthys, Lestodelphys, Phyllotis and Akodon iniscatus among the taxa adapted to more arid and/or colder environments. c-Puesto La Florida

Location: $38^{\circ} 35^{\prime} \mathrm{S}, 61^{\circ} 45^{\prime} \mathrm{W}$; $108 \mathrm{~m}$ height. This site is located at the Sauce Grande River valley between Bajo San José and Las Oscuras localities (Fig. 1, 3.9).

Bearing unit: middle and upper sections of the Agua Blanca Sequence, Chacra La Blanqueada and Matadero Saldungaray formations (Zavala and Quattrocchio, 2001).

Biostratigraphic units recognized in the sequence: type section of the Ozotoceros bezoarticus Zone in the upper section of the Agua Blanca Sequence, and Bos taurus-Ovis aries Zone in upper levels of the Chacra La Blanqueada and Matadero Saldungaray formations (Deschamps, 2005).

Age: Lujanian (Late Pleistocene-Early Holocene) for the Middle Section of the Agua Blanca Sequence; Platan (Late Holocene) for the Upper Section of the Agua Blanca Sequence; Platan (Late Holocene)-Present for the Chacra La Blanqueada Formation at this site; historical times-present for the Matadero Saldungaray Formation (Deschamps, 2005). In the cliffs of the Sauce Grande River near Bajo San José, Borromei (1995) reported radiocarbon datings for the upper section of the Agua Blanca Sequence $(5010 \pm 120$ years $\left.{ }^{14} \mathrm{C} \mathrm{BP}\right)$ and Chacra la Blanqueada Formation $(2830 \pm 90$ years ${ }^{14} \mathrm{C} \mathrm{BP}$ ) which restrict the age to the Middle and Late Holocene respectively. The Chacra La Blanqueada Formation was also dated on peat wood samples between $1570 \pm$ 70 and $900 \pm 50$ years ${ }^{14} \mathrm{C}$ BP at La Toma locality (Rabassa, 1989; Rabassa et al., 1991).

Fossil content: Middle section of the Agua Blanca Sequence: Lama guanicoe. Upper section of the Agua Blanca Sequence: Rhea americana, cf. Anas, Chaetophractus villosus, Zaedyus pichiy, Cavia aperea, and Ozotoceros bezoarticus. Chacra La Blanqueada and Matadero Saldungaray formations: Bos taurus.

8) Napostá Grande Creek valley

a-Chacra Santo Domingo

Location: 38 33' 45.14" S, 62 $04^{\prime} 17.27^{\prime \prime}$ W; 98 m height. This site is in the middle valley of the Napostá Grande Creek; access from Bahía Blanca City is through the road known as La Carrindanga (Figs. 1, 3.10).

Bearing unit: middle and upper sections of the Agua Blanca 


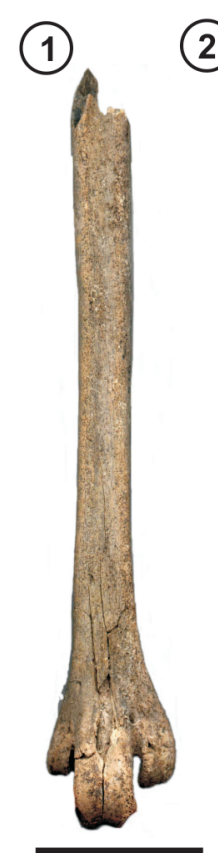

(12)

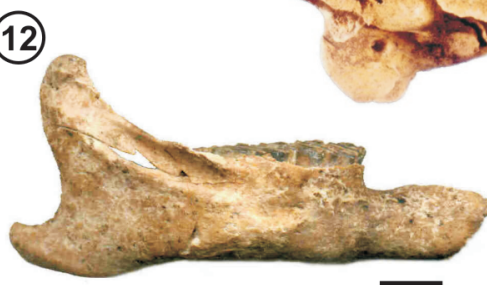

(16)

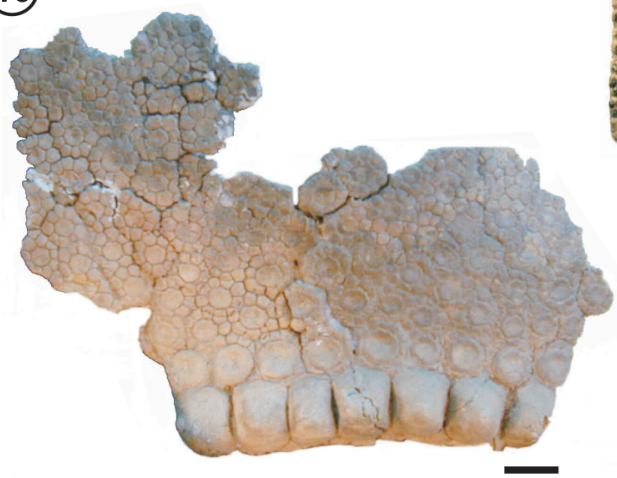

(21)

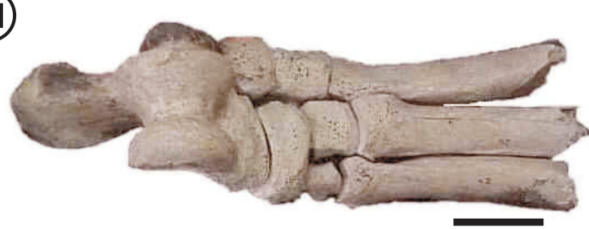

(23)

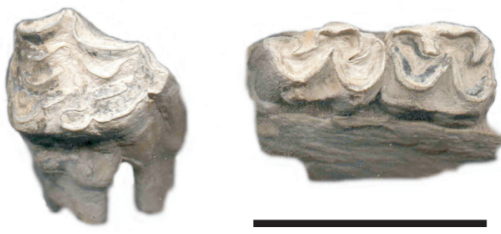

(4)

(13)

(17)
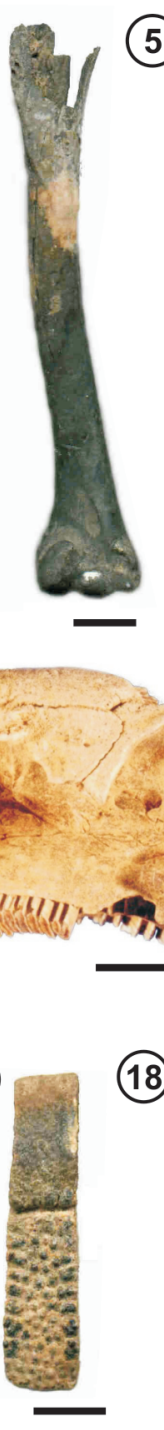

(22)

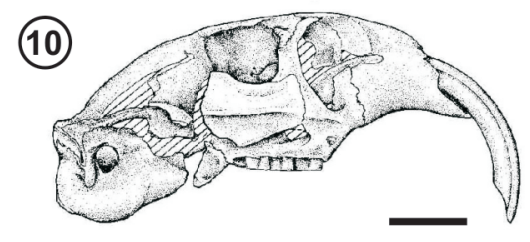

(11)

(14)
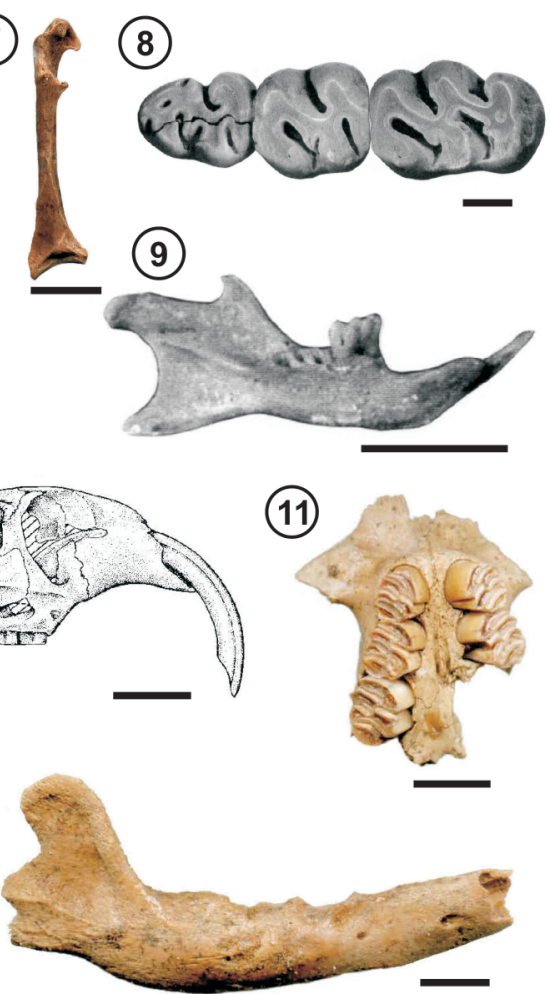

(15)

(19)
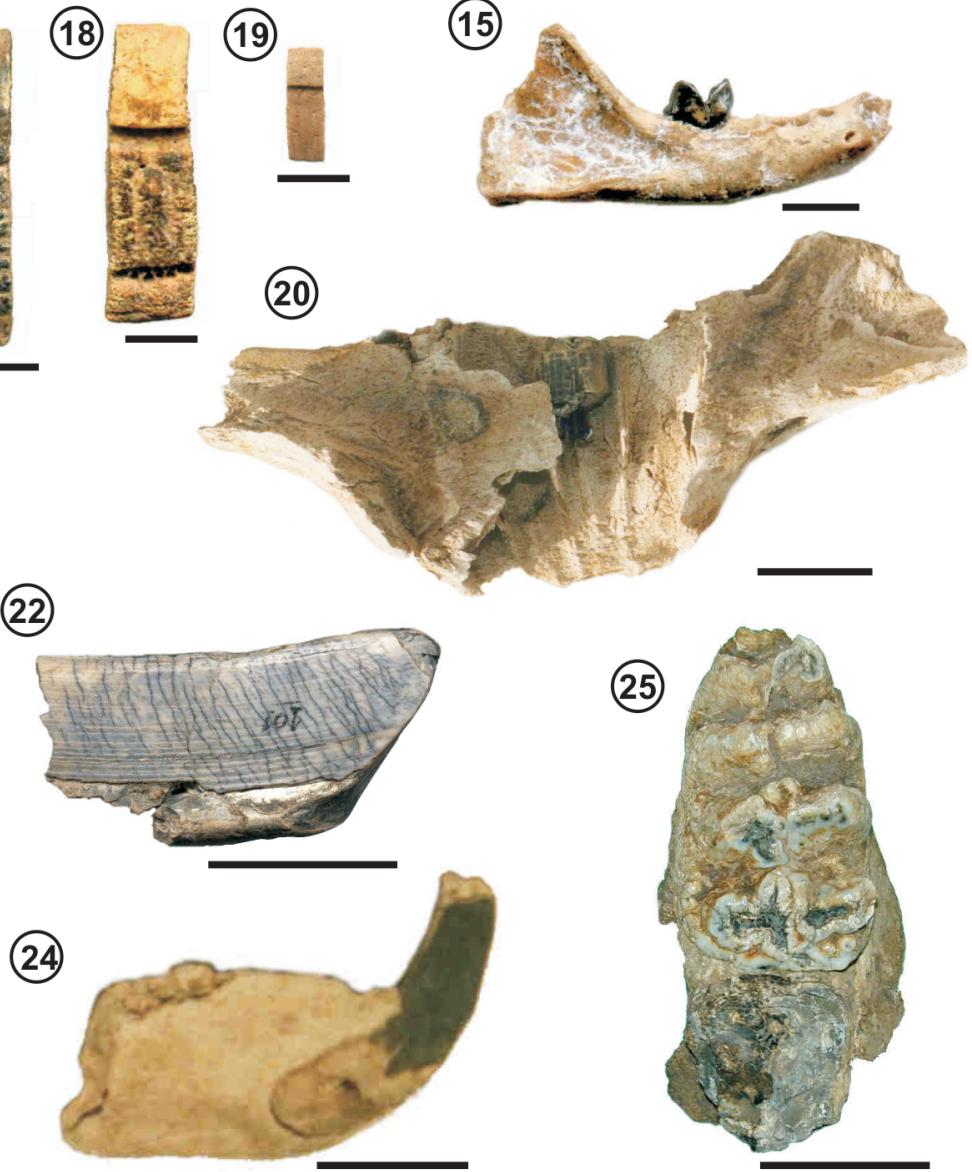

(25)

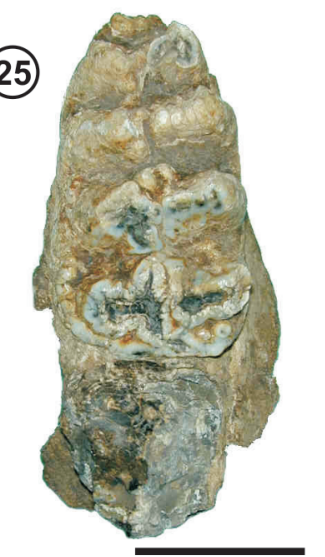


Sequence, Chacra La Blanqueada and Matadero Saldungaray formations (Zavala and Quattrocchio, 2001).

Biostratigraphic units recognized in the sequence: type section of the Equus (Amerhippus) neogaeus-Macrauchenia patachonica Zone, in the middle section of the Agua Blanca Sequence (Deschamps, 2005), and type section of the Bos taurus-Ovis aries Zone in the Matadero Saldungaray Formation.

Age: Lujanian (Late Pleistocene-Early Holocene) for the Middle Section of the Agua Blanca Sequence; Platan (Late Holocene) for the Upper Section of the Agua Blanca Sequence (this unit yielded neospecies and a radiocarbon dating of $1960 \pm 100{ }^{14} \mathrm{C}$ years BP; see Deschamps and Tonni, 1992); Platan (Late Holocene) for the Chacra La Blanqueada Formation at this site; historical times for the Matadero Saldungaray Formation (Deschamps, 2005).

Fossil content: Middle Section of the Agua Blanca Sequence: scarce remains of Rheidae indet., Chaetophractus villosus, Scelidotherium leptocephalum, Macrauchenia patachonica, Lama guanicoe, Lamini indet., and Equus (A.) neogaeus. The Upper Section yielded abundant remains, especially the lower levels: Cyprinodontiformes indet., Anura indet., Rhea sp., Nothura darwini, Tinamidae indet., Anas cf. A. platalea, Dendrocygna sp., and Anatidae indet., Lestodelphys halli, Thylamys cf. T. pusillus, Chaetophractus villosus, Zaedyus pichiy, Holochilus brasiliensis, Calomys cf. C. laucha-musculinus, Reithrodon auritus, Ctenomys sp., Cavia aperea, Lama guanicoe, Ozotoceros bezoarticus, and Pseudalopex aff. P. gymnocercus). Chacra La Blanqueada Formation: Ctenomys talarum and Lama guanicoe. Matadero Saldungaray Formation: Lama guanicoe and Bos taurus (Fig. 9).

b-García del Río
Location: $38^{\circ} 21^{\prime} 49.70^{\prime \prime} \mathrm{S}, 62^{\circ} 09^{\prime} 05.32^{\prime \prime}$ W, 184 m height. Upstream of Napostá Grande village in the Napostá Grande Creek (Figs. 1, 3.11).

Bearing units: Middle and upper sections of the Agua Blanca Sequence, Chacra La Blanqueada and Matadero Saldungaray formations (Zavala and Quattrocchio, 2001).

Biostratigraphic units recognized in the sequence: the recorded taxa were insufficient to recognize any unit.

Age: the Upper Section of the Agua Blanca Sequence has a radiocarbon dating of $2610 \pm 60$ years ${ }^{14} \mathrm{C}$ BP (Quattrocchio et al., 1998), Late Holocene. Chacra La Blanqueada has a radiocarbon dating in this locality of $2342 \pm 47$ years ${ }^{14} \mathrm{C} \mathrm{BP}$ (Tomassini et al., 2014b), Late Holocene.

Fossil content: Lama guanicoe was recorded in all units (Deschamps, 2005). Also, in Chacra La Blanqueada Formation Ctenomys cf. C. talarum, Cavia aperea, and Chaetophractus villosus were recovered (Tomassini et al., 2014b).

10) Playa del Barco

Location: $39^{\circ} 00^{\prime} 09^{\prime \prime} \mathrm{S}, 61^{\circ} 34^{\prime} 52^{\prime \prime} \mathrm{W} ; 0-2 \mathrm{~m}$ height (Figs. 1, 3.12).

Bearing unit: San José Sequence (Zavala and Quattrocchio, 2001).

Biostratigraphic units recognized in the sequence: Equus (Amerhippus) neogeus-Macrauchenia patachonica Zone (Deschamps, 2005).

Age: Lujanian (Late Pleistocene-Early Holocene). A radiocarbonic dating yielded an age of $16.440 \pm 320{ }^{14} \mathrm{C}$ years BF (Aramayo, 1997). Some levels could include Bonaerian (Middle Pleistocene) fauna (see Zavala and Quattrocchio, 2001; Tomassini et al., 2010).

Fossil content: Equus (Amerhippus) neogeus, Macrauchenia patachonica, Glyptodon reticulatus, Doedicurus clavicaudatus,

Figure 8. Some of the specimens found in Bajo San José. 1-7, Aves. 1, tarsus-metatarsus of Rhea sp.; 2-3, Chloephaga sp. 1; 2, left femur; 3, left tarsus-metatarsus; 4-5, Chloephaga sp. 2; 4, right humerus; 5, proximal fragment of left humerus; 6 , right humerus of Motacillinae indet;; 7, left coracoid of cf. Pseudoseisura-Pseudoseisuropsis; 8-13, Rodentia. 8, upper molars of Lundomys sp.; 9, right mandible (inverted) of Akodon cf. A. iniscatus; 10, skull of Ctenomys kraglievichi; 11, palate fragment of Myocastor columnaris; 12, right mandible of Lagostomus sp.; 13, skull of Neochoerus cf. N. tarijensis; 14-15, mandibles of Carnivora. 14, Pseudalopex sp.; 15, cf. Herpailurus; 16-20, Edentata. 16, carapace fragment of Glyptodon clavipes; 17, osteoderm of Tolypeutes sp. nov.; 18, osteoderm of Eutatus seguini; 19, osteoderm of Zaedyus pichiy; 20, right mandible fragment of Megatherium americanum; 21, left posterior autopodium of ?Macraucheniopsis ensenadensis; 22, $3^{\text {rd }}$ left lower incisor fragment of Toxodon sp.; 23, molariforms of Hippidion principale; 24, mandible fragment with incisor of Tayassuinae indet.; 25, molar of Gomphotheriidae indet. Anterior to the right $(8-10,12-15,24)$, to top (11), and to the left (20). Scale $=1 \mathrm{~cm}(2-7,10-12,14-15,17-19), 1 \mathrm{~mm}$ (8), $5 \mathrm{~mm}(9), 5 \mathrm{~cm}(1,13,21-23), 10 \mathrm{~cm}(16,25)$. 
(1)

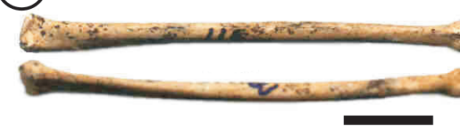

(3)

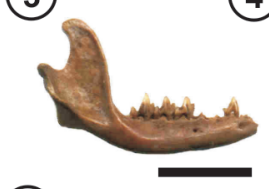

(7)

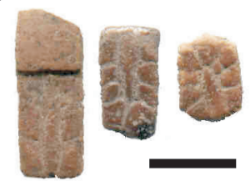

(8)
(2)

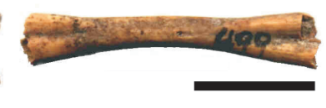

(5)
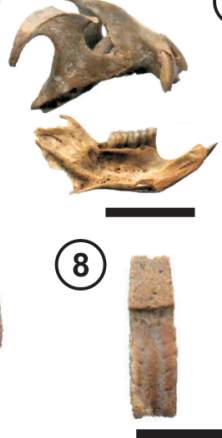

(6)

(9)

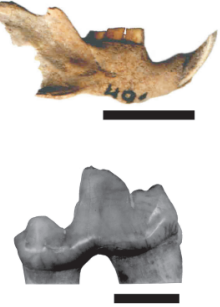

(1)

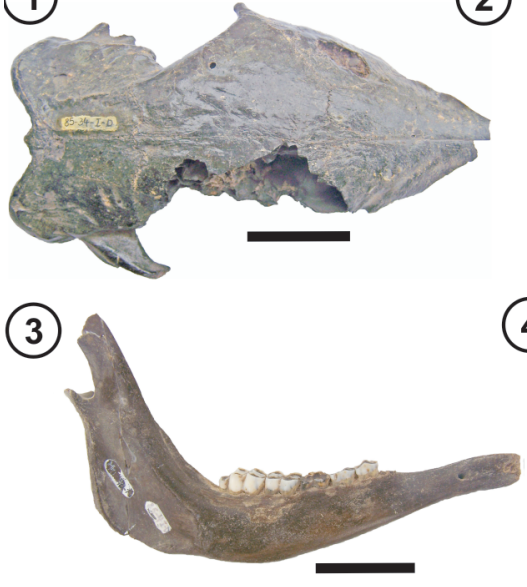

Figure 9. Some of the specimens found in Chacra Santo Domingo, Napostá Grande Creek. 1, Aves, right humerus of Anas cf. A. platalea; 2, tibia-fibula of Bufonidae indet.; 3, left mandible of Lestodelphys halli; 4, fragments of skull and mandible of Reithrodon auritus; 5, right mandible of Holochilus brasiliensis (inverted); 6, mandible of Ctenomys sp.; 7, osteoderms of Chaetophractus villosus; 8, osteoderm of Zaedyus pichiy; 9, p4 of Pseudalopex aff. P. gymnocercus. Anterior to the right $(3-4,6)$ and to the left $(5)$. Scales $=1 \mathrm{~cm}(1-8)$ and $5 \mathrm{~mm}$ (9).

Eutatus seguini, Scelidotherium leptocephalum, Lestodon armatus, Toxodon platensis, Notiomastodon platensis, Morenelaphus bonaerense, Hippidion sp., Smilodon populator, Neochoerus cf. N. tarijensis, among others (Fig. 10; see complete list in Appendix 1).

\section{SYSTEMATIC, BIOCHRONOSTRATIGRAPHIC AND PALEOENVIRONMENTAL COMMENTS}

As mentioned above, since the idea of Mirta Quattrocchio of facing multidisciplinary studies, paleontologic survey in southwestern Buenos Aires Province was increased, and is still increasing today. This was reflected directly in enlarged collections which in turn allowed improving the knowledge of the vertebrate communities that inhabited the area during the last $10 \mathrm{My}$. In this context, those localities in which units formed by fluvial deposits are exposed (e.g., Farola Monte Hermoso, Bajo San José, Playa del Barco), yielded the largest amounts and diversity of bone remains. Together with pollen and ostracodes analyses, vertebrate taxa helped inferring paleoenvironmental, paleoclimatic and

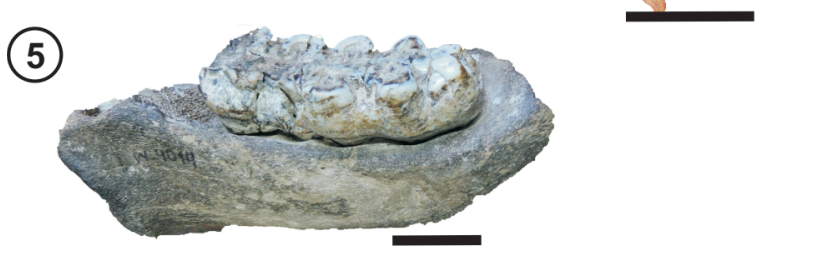

Figure 10. Some of the specimens found in Playa del Barco. 1, skull of Eutatus seguini; 2, fragment of right maxilla of Toxodon platensis; 3 , left hemimandible of Cervidae indet.; 4 , fragment of skull of Morenelaphus sp.; 5, fragment of right hemimandible of Notiomastodon sp. Anterior to the right. Scales $=5 \mathrm{~cm}(1-3), 10 \mathrm{~cm}(4-5)$.

paleobiogeographic conditions both in the Mio-Pliocene and Quaternary.

The age of the late Cenozoic continental deposits and the included fauna is a major issue. Given the scarcity of numerical dating, the age has been almost always determined on the basis of fossil distribution, which makes boundaries and temporal extension of biostratigraphic units at least uncertain and controversial (see Cione and Tonni, 1995, 2005; Verzi et al., 2008; Deschamps et al., 2013). Multidisciplinary studies accomplished in the last years, including detailed fieldwork, paleontological prospection with precise data of stratigraphic provenance, systematics, sedimentological analyses, sequential stratigraphy, taphonomy, magnetostratigraphy, among others, resulted in an improvement of biochronostratigraphic schemes.

One of the main advances in this regard is the inference of the age of "Huayquerian" and "Montehermosan" faunas. Among mammal faunas, rodents are very useful as biostratigraphic tools because of their wide geographic distri- 
bution, and high reproductive and rapid evolutionary rates (Vianey-Liaud et al., 2011). The knowledge of the systematics and phylogeny of several groups of rodents recorded in these intervals has been largely improved in recent years (e.g., Octodontidae, Ctenomyidae, Echimyidae, Hydrochoeridae). This turned out to be quite significant because many of them are good biostratigraphic indicators (Vucetich et al., 2005; Verzi, 2008 and literature therein; Olivares 2009; Olivares et al., 2012; Deschamps et al., 2013 and literature therein).

In the study area, "Huayquerian" faunas were found in Cantera Seminario, Cantera Relleno Sanitario, Cantera Vialidad, and Barrancas de Sarmiento. These localities have in common the record of Xenodontomys ellipticus which is an octodontid rodent that pertains to the ChasichimysXenodontomys lineage. The polarity shown by their anagenetic evolutionary pattern led Verzi et al. (2004b) to propose that $X$. ellipticus is younger than $X$. simpsoni (from Los Salitrales Formation, Buenos Aires Province, and several localities of the Cerro Azul Formation in La Pampa Province) and older than $X$. elongatus (found in the Cerro Azul Formation cropping out at Caleufú, La Pampa Province). It is noteworthy that two other lineages of octodontid rodents (Neophanomys and Reigechimys; Verzi et al., 2011; Sostillo et al., 2014) support the scheme based on the lineage of Xenodontomys. The trend toward increasing hypsodonty observed in the lineage of Xenodontomys and in other caviomorph rodents is related to adaptations to open environments within the climatic deterioration of the Late Miocene (Verzi, 2001). Given that Cantera Vialidad yielded remains of Xenodontomys ellipticus in the same levels and above those which have a numerical dating of $5.28 \pm 0.04$ Ma (Schultz et al., 2006) it may be concluded that "Huayquerian" faunas in this area are latest Miocene-earliest Pliocene in age.

On the other hand, "Montehermosan" faunas were found in Farola Monte Hermoso and Las Oscuras. Deposits of the Monte Hermoso Formation in its type locality Farola Monte Hermoso were accumulated in a dynamic fluvial environment of high-sinuosity rivers ("muddy fine-grained rivers" in Miall, 1985). In these localities, none of the species of Xenodontomys has been recorded, being instead abundant Actenomys priscus, the most derived representative of the lineage Xenodontomys-Actenomys (Verzi, 2008). In addition, when these specimens are compared to specimens of $A$. priscus found in levels assigned to the Chapadmalalan (from the area of Mar del Plata-Miramar), the latter display a more derived dental morphology (Deschamps, 2003; Tomassini et al., 2013a). Preliminary observations (Tomassini, 2012) showed that the specimens of Neophanomys found in Farola Monte Hermoso are also more derived than the species recognized for the Huayquerian Stage/Age of La Pampa (N. pristinus and N. recens), Catamarca (N. biplicatus) and Mendoza (N. biplicatus). Hence the Montehermosan assemblages cannot be older than Early Pliocene because the evolutionary stage of these octodontids (and also other groups of mammals; see Tomassini, 2012; Deschamps et al., 2012; Tomassini et al, 2013a) supports the idea that the bearing sediments of the Monte Hermoso Formation are younger than those of the Cerro Azul Formation at Caleufú with "Huayquerian" fauna.

Another group of rodents found in the area that turned out to be very indicative from a biochronologic point of view are the giant capybaras. The study of the dental evolution of this family resulted in a new interpretation of their taxonomy and systematics which involved the ontogenetic change (Vucetich et al., 2005, 2014a,b, 2015; Deschamps et al., 2007, 2009, 2013). Currently, a single taxon is recognized for each level, and although they were not found in a single stratigraphic sequence to test the proposal, the accompanying fauna supports the different age inferred for each taxon. In "Huayquerian" assemblages only the genus Cardiatherium, with different species, is recorded (Vucetich et al., 2005; 2014b). Instead in "Montehermosan" and "Chapadmalalan" assemblages, Phugatherium is recorded, with two species in the study area, P. cataclisticum in Farola Monte Hermoso and P. novum in the area of Mar del PlataMiramar (Deschamps et al., 2012, 2013). Capybaras were one of the keys to suggest that a single biostratigraphic unit could be determined in the Monte Hermoso Formation at Farola Monte Hermoso, different form the one recognized in the area of Mar del Plata-Miramar. This is supported by other rodent lineages such as the different species of the echimyid rodent Eumysops (Olivares et al., 2012) found in these localities (Deschamps et al., 2012; Tomassini et al., 2013a). 
Concerning the age of the assemblages, the determination of the extension and the boundaries of the represented Stage/Age or SALMA has been long debated, especially those between Huayquerian and Montehermosan. A common use is to extend the boundaries of the different biostratigraphic units represented in a certain interval in order to obtain a continuous sequence, even without numerical dating or faunistic record that support these interpretations. In recent years, taphonomic and sedimentological studies carried out in several localities of the Pampean Region suggested that most assemblages actually represent a very short interval (e.g., Arroyo Chasicó, Laguna Chillhué, Caleufú, Farola Monte Hermoso among others; Tomassini and Montalvo, 2013; Tomassini et al., 2013a,b). We suggest restricting the assemblage duration to the represented interval, considering the existence of hiatuses between the following or previous assemblages instead of extending the duration up to the contiguous unit. In this sense, the assemblages would be like temporal windows in the stratigraphic column, which only show the moment of the assemblage, being the rest hidden. Their relative chronology, and partly the extension of the hiatuses between each other are given by the interpretation of taxonomic differences derived from the processes of anagenesis, extinction and migration (Montalvo et al., 2012; Tomassini et al., 2013b). This idea was somehow implicit when the non-contemporaneity of some "Huayquerian" assemblages was proposed (e.g., Verzi et al., 2008; Deschamps et al., 2013).

Taking a look at the time represented in the studied localities according to the mammal record (see Fig. 2), it is evident that the interval between the Montehermosan and Bonaerian (Chapadmalalan, Marplatan and Ensenadan, or following our scheme, the Late Pliocene-Early Pleistocene) is not represented in the area or has not been found yet. During this interval, even the sedimentological record is poor, because this area would have been affected by erosion processes and no deposition (Quattrocchio et al., 2008). Certainly the regional geological model proposed to explain the geographical distribution and antiquity of the faunal associations will help in elucidating this issue.

The Bonaerian is represented at Bajo San José. The deposits of the San José Sequence in this locality were accumulated by a braided river (Borromei, 1990). The age of the locality was inferred through the record of Ctenomys kraglievichi. This large and peculiar octodontid rodent was also found in Pleistocene localities of the Atlantic coast (Necochea, northern Mar del Plata, and also Uruguay; Verzi et al., 2004a). No absolute dating is known so far for the levels bearing Ctenomys kraglievichi, but biochronological and paleomagnetic data suggest a relative dating of this unit. Among the first ones, the association with Tolypeutes sp. nov. and Hippidion principale, together with Megatherium americanum, Glyptodon clavipes and Panochthus tuberculatus, whose biochrons encompass the Bonaerian-Lujanian. Regarding paleomagnetic data, Ctenomys kraglievichi is recorded at least $2.2 \mathrm{~m}$ above the Bruhnes-Matuyama magnetostratigraphic boundary in northern Mar del Plata, which suggests a younger age than 0.78 Ma.

With respect to the paleoclimatic inferences, C. kraglievichi is associated in Bajo San José and the other localities, with other caviomorph rodents that represent an immigration event triggered by an important warm climatic pulse (Vucetich et al., 1997; Vucetich and Verzi, 2002). The finding of the specimens of Necochea was quite significant. This rodent appears in a single sequence with other micromammal remains. The extinction of the taxa found in older levels is accompanied by the sudden appearance of C. kraglievichi associated with the single record of a post-Pliocene eumysopine echimyid rodent at this latitude, and the single dasyproctid recorded in the Pleistocene of Argentina. Both species and C. kraglievichi are clearly Brazilian immigrants to the southern-southeastern Buenos Aires Province. In Bajo San José, C. kraglievichi is associated with sigmodontine rodents (e.g., Lundomys; Pardiñas and Deschamps, 1996) and a tayassuine also suggesting a strong warm pulse. This warm pulse is in agreement with the relative high sea level proposed for the deposition of the San José Sequence through the analysis of sequence stratigraphy (Zavala and Quattrocchio, 2001). The climatic change identified in the C. kraglievichi Zone may correspond to the warm pulse at 0.4 Ma of the MIS 11 (see discussion in Verzi et al., 2004a).

Mammal remains from the Late Pleistocene in the area are scarce, but suggest that it was a mostly arid period. After the influence of immigrant mammals entering through the Panamá corridor from Central and North America in the 
set of events known as GABI (Great American Biotic Interchange), the composition of the mammal assemblages was already established. The major changes observed since the extinction of the megafauna are mostly due to responses to climatic-environmental change. The reaction is more evident in those populations that inhabit the extremes of the geographical distribution of the species (Millien et al., 2006, and literature therein). Precisely, the southwest of the Buenos Aires Province is an ecotonal area between the Guayano-Brasileña and Andino-Patagónica Subregions (sensu Ringuelet, 1961), where the extremes of the geographical distribution of the species from both subregions are in close interaction.

This interval is recorded in Puesto La Florida, Chacra La Blanqueada, García del Río, Balneario Saldungaray, and Playa del Barco. The deposits are similar to those found in the banks of rivers and creeks of the east of the Buenos Aires Province (the Pampa Ondulada and Interserrana) with Lujanian deposits. They correspond mainly to channel deposits of plains rivers with differences related to the proximity of the ranges.

Holocene deposits are recorded in the same localities, overlying the Late Pleistocene levels. They are also similar to those of the Pampa Ondulada and Interserrana where the Platan was recognized. Most of the remains were found in the upper levels of the middle section of the Agua Blanca Sequence. In this sector of the profile, a conspicuous lamination is observed. The best represented locality of this interval is Chacra Santo Domingo, where a Brazilian and/or aquatic vertebrate fauna (fish, anurans, Anas platalea, Dendrocygna, Holochilus brasiliensis and Cavia aperea) agree with the hydrophytic communities found in pollen analyses. The southern expansion of Brazilian fauna coexisted with central and Patagonian elements (Chaetophractus villosus, Zaedyus pichiy, Lama guanicoe, Reithrodon auritus, Pseudalopex gymnocercus, among others) suggesting the amelioration of previous arid and semiarid conditions. As well, water bodies could have locally modified the arid conditions favoring the ingression of the Brazilian fauna, and the presence of endemic forms could have been favored by the influence of the nearby ranges (Quattrocchio et al., 1988; Deschamps and Tonni, 1992).

\section{ACKNOWLEDGMENTS}

This contribution is dedicated to Dr. Mirta E. Quattrocchio who greatly influenced and helped in our careers. The revisions of Dr. M.G. Vucetich and Dr. D.H. Verzi greatly improved the manuscript. CMD thanks Mr. Heraclio Ortiz who helped enormously in fieldwork with enthusiasm and good humor, and found many of the studied specimens. Research was partially supported by the Agencia Nacional de Promoción Científica y Tecnológica (PICT 2012-1483 and PICT 2012-2674), and Programa de Incentivos N645, UNLP, Argentina.

\section{REFERENCES}

Agnolin, F., and Tomassini, R.L. 2012. Fossil Dendrocygninae (Aves, Anatidae) from the Early Pliocene of the Argentine Pampas and its paleobiogeographical implications. Annales de Paléontologie 98: 191-201.

Agnolin, F., Bogan, S., Tomassini, R.L., and Manera, T. 2014. Nuevo Percichthyidae (Teleostei, Percoidei) del Plioceno temprano de la provincia de Buenos Aires (Argentina) y sus implicancias biogeográficas. Revista del Museo Argentino de Ciencias Naturales (n.s.) 16: 19-31.

Albino, A., Tomassini, R.L., and Brizuela, S. 2009. Presencia del lagarto teiido Tupinambis en la Formación Monte Hermoso de Farola Monte Hermoso, sur de la provincia de Buenos Aires (Argentina). Ameghiniana 46: 177-187.

Ameghino, F. 1887. Monte Hermoso. Diario La Nación, Buenos Aires, 10 de Marzo: 1-10.

Ameghino, F. 1889. Contribución al Conocimiento de los Mamíferos Fósiles de la República Argentina. Academia Nacional Ciencias (Córdoba), Actas 4: 1-1027.

Ameghino, F. 1898. Sinopsis geológico-paleontológica. Segundo Censo de la República Argentina 1: 111-255.

Ameghino, F. 1908. Las formaciones sedimentarias de la región litoral de Mar del Plata y Chapalmalán. Anales del Museo Nacional de Buenos Aires, Serie 3, 10: 343-428.

Aramayo, S.A. 1997. Cronología radiocarbónica de localidades fosilíferas pleistocenas y holocenas de la costa sud-sudeste de la provincia de Buenos Aires, Argentina. $6^{\circ}$ Congresso da Associação Brasileira de Estudos do Quaternário e Reunido sobre o Quaternário da América do Sul (Curitiba, Paraná), Resúmenes: 305-308.

Aramayo, S.A., and Manera de Bianco, T. 1989. Nuevos hallazgos de mamíferos pleistocénicos en el yacimiento de Playa del Barco, provincia de Buenos Aires. $1^{\circ}$ Jornadas Geológicas Bonaerenses (Tandil), Actas: 701-712.

Bonaparte, J. 1960. La sucesión estratigráfica de Monte Hermoso (Provincia de Buenos Aires). Acta Geológica Lilloana 3: 273-278.

Borromei, A.M. 1990. A Braided fluvial system in Pleistocenic sediments in southern Buenos Aires Province, Argentina. Quaternary of South America and Antarctic Peninsula 6: 221-233.

Borromei, A.M. 1995. Palinología, estratigrafía y paleoambientes del Pleistoceno Tardío-Holoceno en el valle del río Sauce Grande, provincia de Buenos Aires, Argentina. Polen 7: 19-31.

Bravard, A. 1857. Observaciones geológicas sobre diferentes terrenos de transporte en la hoya del Plata. Biblioteca Diario La Prensa, Imprenta y Literatura Bernheim, Buenos Aires, 80 p.

Cabrera, A. 1929. Revisión de los mastodontes argentinos. Revista del Museo de La Plata 32: 61-144.

Comité Argentino de Estratigrafía. 1992. Código Argentino de Estratigrafía. Asociación Geológica Argentina, Serie B (Didáctica y Complementaria) N²0: 1-64. 
Chebli, G.A., Mozetic, M.E., Rosello, E.A., and Bühler, M. 1999. Cuencas sedimentarias de la Ilanura Chacopampeana. In: R. Caminos (Ed.), Geología Argentina. Anales Servicio Geológico Minero Argentino, Instituto de Geología y Recursos Minerales, Buenos Aires 29: 627-644.

Cione, A.L., and López Arbarello, A. 1995. Los peces de agua dulce fósiles del área pampeana. In: M.T. Alberdi, G. Leone, and E.P. Tonni (Eds.), Evolución biológica y climática de la región pampeana durante los últimos cinco millones de años. Monografías del Museo Nacional de Ciencias Naturales de Madrid, Madrid, 12: $131-142$.

Cione, A.L., and Tonni, E.P. 1995. Chronostratigraphy and "Land mammal ages" in the Cenozoic of southern South America: principles, practices and the "Uquian" problem. Journal of Paleontology 69: 135-159.

Cione, A.L., and Tonni, E.P. 2005. Biostratigrafía basada en mamíferos del Cenozoico superior de la provincia de Buenos Aires, Argentina. In: R.E. de Barrio, R.O. Etcheverry, M.F. Caballé, and E. Llambías (Eds.), Relatorio del $16^{\circ}$ Congreso Geológico Argentino. Geología y Recursos Minerales de la Provincia de Buenos Aires, La Plata, Quick Press, Industria Gráfica, p. 183-200.

Darwin, C. 1846. Geological observations on South America, being the third part of the Geology of the voyage of the Beagle, under the command of Captain Fitz Roy, R. N. during the years 1832 to 1836. Smith, Elder and Co., London, 279 p.

De Francesco, F. 1992. Estratigrafía del Cenozoico en el flanco occidental de las Sierras de Curamalal. Sierras Australes Bonaerenses. $3^{\circ}$ Jornadas Geológicas Bonaerenses (La Plata), Actas: 3-12.

De la Fuente, M.S. 1992. Las tortugas Chelidae del Terciario Superior y Cuaternario del territorio argentino. Ameghiniana 29: 211-229.

De la Fuente, M.S. 1999. A review of the Pleistocene reptiles of Argentina: Taxonomic and palaeoenvironmental considerations. Quaternary of South America and Antarctic Peninsula 12: 109-136.

Deschamps, C.M. 1998. The presence of Neochoerus Hay (Rodentia, Hydrochoeridae) in Pleistocenic sediments of southwestern Buenos Aires Province. Quaternary of South America and Antarctic Peninsula 11: 1-14.

Deschamps, C.M. 2003. [Estratigrafía y paleoambientes del Cenozoico en el sur de la Provincia de Buenos Aires. El aporte de los vertebrados. PhD dissertation, Universidad Nacional de La Plata, La Plata, 317 p. Unpublished.].

Deschamps, C.M. 2005. Late Cenozoic mammal bio-chronostratigraphy in southwestern Buenos Aires Province, Argentina. Ameghiniana 42: 733-750.

Deschamps, C.M., and Borromei, A.M. 1992. La fauna de vertebrados pleistocénicos del Bajo San José (Provincia de Buenos Aires, Argentina). Aspectos paleoambientales. Ameghiniana 29: 177-183.

Deschamps, C.M., and Tonni, E.P. 1992. Los vertebrados del Pleistoceno tardío Holoceno del Arroyo Napostá Grande, Provincia de Buenos Aires. Aspectos paleoambientales. Ameghiniana 29: 201-211.

Deschamps, C.M., Borromei, A.M., and Zavala, C.A. 1989. Hallazgo de mamíferos fósiles en "Sedimentos Pampeanos", Paraje "Las Obscuras" (provincia de Buenos Aires). 70 Jornadas de Paleontología de Vertebrados (Buenos Aires), Actas: 90-92.

Deschamps, C.M., Olivares, A.I., Vieytes, E.C., and Vucetich, M.G. 2007. Ontogeny and diversity of the oldest capybaras (Rodentia, Hydrochoeridae; Late Miocene of Argentina). Journal of Vertebrate Paleontology 27: 683-692.

Deschamps, C.M., Tonni, E.P., Verzi, D.H., Scillato-Yané, G.J., Zavala, C.A., Carlini, A.A., and Di Martino, V. 1998. Bioestratigrafía del Cenozoico superior continental en el área de Bahía Blanca, pro- vincia de Buenos Aires. $5^{\circ}$ Jornadas Geológicas y Geofísicas Bonaerenses (Mar del Plata), Actas 1: 49-57.

Deschamps, C.M., Verzi, D.H., and Vucetich, M.G. 2000. Presencia de Myocastor (Rodentia, Myocastoridae) en el Ensenadense del SO de la Provincia de Buenos Aires. Ameghiniana, Suplemento Resúmenes 37: R72-R73.

Deschamps, C.M., Vieytes, E.C., Olivares, A.I., and Vucetich, M.G. 2009. Primer registro de Cardiatherium chasicoense (Rodentia, Hydrochoeridae) fuera del área pampeana (Argentina) y su valor bioestratigráfico. Ameghiniana 46: 295-305.

Deschamps, C.M., Vucetich, M.G., Montalvo, C.I., and Zárate, M.A. 2013. Capybaras (Rodentia, Hydrochoeridae, Hydrochoerinae) and their bearing in the calibration of the late Miocene-Pliocene sequences of South America. Journal of South American Earth Sciences 48: 145-158.

Deschamps, C.M., Vucetich, M.G., Verzi, D.H., and Olivares, A.I. 2012. Biostratigraphy and correlation of the Monte Hermoso Formation (early Pliocene, Argentina): The evidence from caviomorph rodents. Journal of South American Earth Sciences 35: 1-9.

Fidalgo, F., De Francesco, O., and Colado, U.R. 1973. Geología superficial de las hojas Castelli, J. M. Cobo y Monasterio (Provincia de Buenos Aires). $5^{\circ}$ Congreso Geológico Argentino (Córdoba), Actas 4: 27-39.

Figini, A., Rabassa, J., Tonni, E.P., Huarte, R., Gómez, G., Carbonari, J., and Zubiaga, A. 1989. Dataciones radiocarbónicas de gasterópodos terrestres en sedimentos del Pleistoceno superior y Holoceno del valle del río Sauce Grande, provincia de Buenos Aires. $1^{\circ}$ Jornadas Geológicas Bonaerenses (Tandil), Actas: 809824.

Folguera, A., and Zárate, M.A. 2009. La sedimentación neógena continental en el sector extraandino de Argentina central. Revista de la Asociación Geológica Argentina 64: 692-712.

Folguera, A., and Zárate, M.A. 2011. Neogene sedimentation in the foreland zone between $34^{\circ} 30^{\prime}$ and $41^{\circ} \mathrm{S}$ and its relation to the Pampa Central block uplift and the tectonic Colorado basin. In: J. Salfiti, and R. Marquillas (Eds.), Cenozoic Geology of Central Andes of Argentina. Instituto del Cenozoico, Salta, p. 123-134.

Frenguelli, J. 1928. Observaciones geológicas en la región costanera sur de la Provincia de Buenos Aires. Anales de la Facultad de Ciencias de la Educación 2: 1-154.

Frenguelli, J. 1950. Rasgos generales de la morfología y la geología de la provincia de Buenos Aires. Laboratorio de Ensayo de Materiales e Investigaciones Tecnológicas, Ministerio de Obras Públicas, provincia de Buenos Aires, Serie 2, 33: 1-72.

Furque, G. 1967. Estratigrafía de la Región de Pillahuincó. Acta Geológica Lilloana 9: 79-114.

Gasparini, G.M. 2013. Records and Stratigraphical Ranges of South American Tayassuidae (Mammalia, Artiodactyla). Journal of Mammalian Evolution 20: 57-68.

Kraglievich, L. 1926. Presencia del género Nothrotherium Lydekker (=Coelodon Lund) en la fauna pampeana. Nothrotherium torresin. sp. Revista del Museo de La Plata 29: 1-18.

Kraglievich, L. 1934. La antigüedad pliocena de las faunas de Monte Hermoso y Chapadmalal, deducida de su comparación con las que les precedieron y sucedieron. Imprenta El Siglo Ilustrado, Montevideo, p. 1-136.

Kraglievich, J.L. 1946. Resultados de una excursión a Monte Hermoso y sus zonas vecinas. Holmbergia 4: 197-213.

Leanza, A. 1948. Nota preliminar sobre la geología de las Barrancas de Monte Hermoso (Provincia de Buenos Aires). Notas del Museo de La Plata 13, Geología 48: 3-6. 
Miall, A.D. 1985. Architectural-element analysis: a new method of facies analysis applied to fluvial deposits. Earth Science Reviews 22: 261-308.

Millien, V., Lyons, S.K., Olson, L. Smith, F.A., Wilson, A.B., and YomTov, Y. 2006. Ecotypic variation in the context of global climate change: revisiting the rules. Ecology Letters 9: 853-869.

Miño-Boilini, A., Tomassini, R.L., Manera de Bianco, T., and Oliva, C. 2011. Adiciones al conocimiento de Proscelidodon Bordas (Mammalia, Xenarthra, Scelidotheriinae). Revista Brasileira de Paleontologia 14: 269-278.

Montalvo, C.I., Zárate, M.A., and Folguera, A. 2012. Evolución geológica y patrón de distribución del registro de vertebrados fósiles neógenos del centro de Argentina $\left(33^{\circ}-40^{\circ} \mathrm{S}\right)$. Ameghiniana Suplemento Resúmenes 44: 13R.

Olivares, A.I. 2009. [Anatomía, sistemática y evolución de los roedores caviomorfos sudamericanos del género Eumysops (Rodentia, Echimyidae). PhD thesis, Universidad Nacional de La Plata, 236 p. Unpublished.].

Olivares A.I, Verzi, D.H., and Vucetich, M.G. 2012. Definición del género Eumysops Ameghino, 1888 (Rodentia, Echimyidae) y revisión de las especies del Plioceno temprano de Argentina central. Ameghiniana 49: 198-216.

Pardiñas, U.F.J., and Deschamps, C.M. 1996. Sigmodontinos (Mammalia, Rodentia) pleistocénicos del sudoeste de la provincia de Buenos Aires (Argentina): aspectos sistemáticos, paleozoogeográficos y paleoambientales. Estudios Geológicos 52: 367-379.

Pardiñas, U.F.J., and Teta, P. 2011. Fossil history of the marsh rats of the genus Holochilus and Lundomys (Cricetidae, Sigmodontinae) in southern South America. Estudios Geológicos 67: 111129.

Parodi Bustos, R. 1962. Los mastodontes sudamericanos y su clasificación, con descripción de nuevos ejemplares descubiertos en la Provincia de Salta. Cuaderno de la Revista de la Facultad de Ciencias Naturales 2: 5-41.

Pascual, R. 1961. Un nuevo Cardiomyinae (Rodentia, Caviidae) de la Formación Arroyo Chasicó (Plioceno inferior) de la Provincia de Buenos Aires. Ameghiniana 2: 61-71.

Pascual, R., and Bondesio, P. 1982. Un roedor Cardiatheriinae (Hydrochoeridae) de la Edad Huayqueriense (Mioceno tardío) de La Pampa. Sumario de los ambientes terrestres en la Argentina durante el Mioceno. Ameghiniana 19: 19-35.

Pascual, R., Ortega Hinojosa, E.J., Gondar, D., and Tonni, E.P. 1965. Las edades del Cenozoico mammalífero de la Argentina, con especial atención a aquellas del territorio bonaerense. Anales de la Comisión de Investigaciones Científicas de la Provincia de Buenos Aires 6: 165-193.

Prevosti, F.J. 2006. New material of Pleistocene cats (Carnivora, Felidae) from Southern South America, with comments on biogeography and the fossil record. Geobios 39: 679-694.

Quattrocchio, M.E., Borromei, A.M., Deschamps, C.M., Grill, S.C., and Zavala, C.A. 2008. Landscape evolution and climate changes in the Pleistocene-Holocene, southern Pampa (Argentina). Evidence from palynology, mammals and sedimentology. Quaternary International 181: 123-138.

Quattrocchio, M.E., Deschamps, C.M., Martinez, D., Grill, S.C., and Zavala, C.A. 1988. Caracterización paleontológica y paleoambiental de sedimentos cuaternarios, Arroyo Napostá Grande, provincia de Buenos Aires. $2^{\circ}$ Jornadas Geológicas Bonaerenses (Bahía Blanca), Actas: 37-46.

Quattrocchio, M.E., Grill, S.C., and Zavala, C.A. 1998. Chronostratigraphic and palynozone chronosequence charts of Napostá Grande Creek, Southwestern Buenos Aires Province, Argentina.
Quaternary of South America and Antarctic Peninsula 11: 111-133.

Rabassa, J. 1989. Geología de los depósitos del Pleistoceno Superior y Holoceno en las cabeceras del río Sauce Grande, provincia de Buenos Aires. $1^{\circ}$ Jornadas Geológicas Bonaerenses (Tandil), Actas: 765-790.

Rabassa, J., Heusser, C., Salemme, M., Politis, G., and Stuckenrath, R. 1991. Troncos de Salix humboldtiana en depósitos aluviales del Holoceno tardío, Río Sauce Grande (Provincia de Buenos Aires, Argentina). Cuadernos de Geografía 3: 221-236.

Rasia, L.L. 2016. [Los Chinchillidae (Rodentia, Caviomorpha) fósiles de la República Argentina: sistemática, historia evolutiva y biogeográfica, significado bioestratigráfico y paleoambiental. PhD Dissertation, Universidad Nacional de La Plata, La Plata, 297 p. Unpublished.].

Reig, O.A. 1955. Un nuevo género y especie de cenolestinos del Plioceno de la Provincia de Buenos Aires (República Argentina). Revista de la Asociación Geológica Argentina 10: 60-71.

Ringuelet, R.A. 1961. Rasgos fundamentales de la zoogeografía de la República Argentina. Physis 22: 151-170.

Schultz, P.H., Zárate, M.A., Hames, W.E., Harris, R.S., Bunch, T.E., Koeberl, C., Renne, P., and Wittke, J. 2006. The record of Miocene impacts in the Argentine Pampas. Meteoritics and Planetary Science 41: 749-771.

Sostillo, R., Montalvo, C.I., and Verzi, D.H. 2014. A new species of Reigechimys (Rodentia, Echimyidae) from the late Miocene of central Argentina and the evolutionary pattern of the lineage. Ameghiniana 51: 284-294.

Tomassini, R.L. 2012. [Estudio taxonómico y bioestratigráfico de los vertebrados de la Formación Monte Hermoso (Plioceno) en su localidad tipo, provincia de Buenos Aires. PhD dissertation, Universidad Nacional del Sur, 300 p. Unpublished.].

Tomassini, R.L., Agnolin, F., and Oliva, C. 2011. First fossil record of the genus Lepidobatrachus Budgett, 1899 (Anura, Ceratophryidae) from the early Pliocene of Argentina. Journal of Vertebrate Paleontology 31: 1005-1009.

Tomassini, R.L., Frontini, R., and Bayón, C. 2014b. Taphonomic analysis of an assemblage of Lama guanicoe (Artiodactyla, Camelidae) from late Holocene (Pampean Region, Argentina). Palaios 29: 570-577.

Tomassini, R.L., and Montalvo, C. 2010. Coprolitos en la Formación Monte Hermoso, Farola Monte Hermoso, Buenos Aires, Argentina. Ameghiniana 47: 111-115.

Tomassini, R.L., and Montalvo, C. 2013. Taphonomic modes on fluvial deposits of the Monte Hermoso Formation (early Pliocene), Buenos Aires province, Argentina. Palaeogeography, Palaeoclimatology, Palaeoecology 369: 282-294.

Tomassini, R.L., Montalvo, C.I., Deschamps, C.M., and Manera, T. 2013a. Biostratigraphy and biochronology of the Monte Hermoso Formation (early Pliocene) at its type locality, Buenos Aires Province, Argentina. Journal of South American Earth Sciences 48: 31-42.

Tomassini, R.L., Montalvo, C.I., Manera, T., and Oliva, C. 2010. Estudio tafonómico de los mamíferos pleistocenos del yacimiento de Playa del Barco (Pehuén Co), provincia de Buenos Aires, Argentina. Ameghiniana 47: 137-152.

Tomassini, R.L., Montalvo, C.I., Visconti, G., and Manera, T. $2014 \mathrm{a}$. Mineralogy, geochemistry and paleohistology of Pliocene mammals from the Monte Hermoso Formation (Argentina). Paedotherium bonaerense (Notoungulata, Hegetotheriidae) as case study. Ameghiniana 51: 385-395.

Tomassini, R.L., Montalvo, C.I., Zárate, M.A., Deschamps, C.M., and 
Vucetich, M.G. 2013b. Ventanas temporales, un concepto útil en el análisis biocronoestratigráfico del Mioceno tardío-Plioceno temprano de Argentina. $2^{\circ}$ Simposio del Mioceno-Pleistoceno del Centro y Norte de Argentina (Diamante), Actas: 27.

Tonni, E.P., and Deschamps, C.M. 2001. Las Aves del Ensenadense en el sudoeste de la provincia de Buenos Aires. Ameghiniana, Suplemento Resúmenes 38: 41-42.

Tonni, E.P., and Noriega, J.I. 2001. Una especie extinta de Pseudoseisura Reichenbach 1853 (Passeriformes: Furnariidae) del Pleistoceno de la Argentina: comentarios filogenéticos. Ornitologia Neotropical 12: 29-44.

Tonni, E.P., Prado, J.L., Fidalgo, F., and Laza, J.H. 1992. El Piso/Edad Montehermosense (Plioceno) y sus mamíferos. $3^{\circ}$ Jornadas Geológicas Bonaerenses (La Plata), Actas: 113-118.

Verzi, D.H. 1999. The dental evidence on the differentiation of the ctenomyine rodents (Caviomorpha, Octodontidae, Ctenomyinae). Acta Theriologica 44: 263-282.

Verzi, D.H. 2001. Phylogenetic position of Abalosia and the evolution of the extant Octodontinae (Rodentia, Caviomorpha, Octodontidae). Acta Theriologica 46: 243-268.

Verzi, D.H. 2008. Phylogeny and adaptive diversity of rodents of the family Ctenomyidae (Caviomorpha): delimiting lineages and genera in the fossil record. Journal of Zoology 274: 386-394.

Verzi, D.H., and Deschamps, C.M. 1996. Presencia de roedores ctenominos del género Xenodontomys en Loma Sarmiento, Provincia de Buenos Aires. $3^{\circ}$ Jornadas Geológicas y Geofísicas bonaerenses (Junín), Actas 1: 47-54.

Verzi, D.H., Deschamps, C.M., and Tonni, E.P. 2004a. Biostratigraphic and paleoclimatic meaning of the Middle Pleistocene South American rodent Ctenomys kraglievichi (Caviomorpha, Octodontidae). Palaeogeography, Palaeoclimatology, Palaeoecology 212: 315-329.

Verzi, D.H., Deschamps, C.M., and Vucetich, M.G. 2002. Sistemática y antigüedad de Paramyocastor diligens (Rodentia, Caviomorpha, Myocastoridae). Ameghiniana 39: 193-200.

Verzi, D.H., Montalvo, C.I., and Deschamps, C.M. 2008. Biostratigraphy and biochronology of the Late Miocene of central Argentina: Evidence from rodents and taphonomy. Geobios 41: 145-155.

Verzi, D.H., Vieytes, E.C., and Montalvo, C.I. 2004b. Dental evolution in Xenodontomys and first notice on secondary acquisition of radial enamel in rodents (Rodentia, Caviomropha, Octodontidae). Geobios 37: 795-806.

Verzi, D.H., Vieytes, E.C., and Montalvo, C.I. 2011. Dental evolution in Neophanomys (Rodentia, Octodontidae) from the Late Miocene of central Argentina. Geobios 44: 621-633.

Vianey-Liaud, M., Gomes-Rodrigues, H., and Michaux, J. 2011. L'espèce en paléontologie: de l'utilisation du binôme linnéen chez les rongeurs fossiles (Mammalia, Rodentia). Comptes Rendus Palevol 10: 117-131.

Vucetich, M.G., Deschamps, C.M., and Pérez, M.E. 2015. The first capybaras (Rodentia, Caviidae, Hydrochoerinae) involved in the Great American Biotic Interchange. Ameghiniana 52: 324-333.
Vucetich, M.G., Deschamps, C.M., Pérez, M.E., and Montalvo, C.I. 2014b. The taxonomic status of the Pliocene capybaras (Rodentia) Phugatherium Ameghino and Chapalmatherium Ameghino. Ameghiniana 51: 173-183.

Vucetich, M.G., Deschamps, C.M., Olivares, A.I., and Dozo, M.T. 2005. Capybaras, shape, size and time: a model kit. Acta Paleontologica Polonica 50: 259-272.

Vucetich, M.G., Deschamps, C.M., Vieytes, E.C., and Montalvo, C.I. 2014a. Late Miocene capybaras (Rodentia, Cavioidea, Hydrochoeridae): skull anatomy, taxonomy, evolution and biochronology. Acta Paleontologica Polonica 59: 517-535.

Vucetich, M.G., and Verzi, D.H. 2002. First record of Dasyproctidae (Rodentia) in the Pleistocene of Argentina: paleoclimatic implications. Palaeogeography, Palaeoclimatology, Palaeoecology 178: 67-73.

Vucetich, M.G., Verzi, D.H., and Tonni, E.P. 1997. Paleoclimatic implications of the presence of Clyomys (Rodentia, Echimyidae) in the Pleistocene of central Argentina. Palaeogeography, Palaeoclimatology, Palaeoecology 128: 207-214.

Zambrano, J.J. 1972. La cuenca del Colorado. In: A. Leanza (Ed.) Geología Regional Argentina. Academia Nacional de Ciencias, Córdoba, p. 419-438.

Zárate, M.A. 2005. El Cenozoico tardío continental de la provincia de Buenos Aires. In: R. de Barrio, R. Etcheverry, M. Caballé, and E. Llambías (Eds.), Relatorio del $16^{\circ}$ Congreso Geológico Argentino.Geología y Recursos Minerales de la provincia de Buenos Aires, La Plata, Quick Press, Industrias Gráficas, p. 39-149.

Zavala, C.A. 1993. Estratigrafía de la localidad de Farola Monte Hermoso (Plioceno-Reciente). Provincia de Buenos Aires. $12^{\circ} \mathrm{Con}$ greso Geológico Argentino y $2^{\circ}$ Congreso de Exploración de Hidrocarburos (San Juan), Actas 2: 228-235.

Zavala, C.A., and Quattrocchio, M.E. 2001. Estratigrafía y evolución geológica del río Sauce Grande (Cuaternario), provincia de Buenos Aires. Revista de la Asociación Geológica Argentina 56: 2537.

Zurita, A., and Tomassini, R.L. 2006. Revisión de un Hoplophorini poco conocido "Sclerocalyptus" lineatus Ameghino (Mammalia, Xenarthra, Glyptodontidae) de edad Montehermosense (Mioceno tardío-Plioceno temprano) de la Argentina. Studia Geologica Salmanticensia 42: 11-20.

Doi: 10.5710/PEAPA.06.05.2016.113

Recibido: 30 de marzo de 2016

Aceptado: 6 de mayo de 2016 
Appendix 1. Systematic list. Record in the studied localities.

\begin{tabular}{|c|c|c|c|c|c|c|c|c|c|c|c|c|}
\hline \multirow[t]{2}{*}{ Taxa } & \multicolumn{12}{|c|}{ Localities } \\
\hline & $C S$ & BSar & $C V$ & CRS & $F M H$ & $L O$ & Bals & BSJ & $P L F$ & CSD & $G d R$ & $P d B$ \\
\hline \multicolumn{13}{|l|}{ Class Osteichthyes } \\
\hline \multicolumn{13}{|l|}{ Order Siluriformes } \\
\hline Pimelodella aff. P. laticeps Eigenmann, 1917 & & & & & & & & $x$ & & & & \\
\hline Callichthys callichtys Linné, 1758 & & & & & & & & $x$ & & & & \\
\hline Corydoras Cf. C. paleatus (Jenyns, 1842) & & & & & & & & $x$ & & & & \\
\hline Siluriformes indet. & & & & & $x$ & & & & & & & \\
\hline Trichomycteridae indet. & & & & & $x$ & & & & & & & \\
\hline \multicolumn{13}{|l|}{ Order Perciformes } \\
\hline Percichthys $s p$. & & & & & & & & $x$ & & & & \\
\hline Plesiopercichthys dimartinoi Agnolin et al., 2014 & & & & & $x$ & & & & & & & \\
\hline \multicolumn{13}{|l|}{ Order Characiformes } \\
\hline Characidae indet. & & & & & $x$ & & & & & & & \\
\hline \multicolumn{13}{|l|}{ Class Amphibia } \\
\hline \multicolumn{13}{|l|}{ Order Anura } \\
\hline Rhinella cf. R. pisanoi Casamiquela, 1967 & & & & & $x$ & & & & & & & \\
\hline Rhinella cf. R. schneideri Werner, 1894 & & & & & $x$ & & & & & & & \\
\hline Ceratophrys ameghinorum Fernicola, 2001 & & & & & $x$ & & & & & & & \\
\hline Lepidobatrachus australis Nicoli, 2015 & & & & & $x$ & & & & & & & \\
\hline Leptodactylus $s p$. & & & & & $x$ & & & & & & & \\
\hline \multicolumn{13}{|l|}{ Class Reptilia } \\
\hline \multicolumn{13}{|l|}{ Order Chelonii } \\
\hline Chelonoidis australis (Moreno, 1889) & & & & & $x$ & & & & & & & \\
\hline Hydromedusa tectifera (Cope, 1869) & & & & & & & & $x$ & & & & \\
\hline \multicolumn{13}{|l|}{ Order Squamata } \\
\hline Tupinambis $s p$. & & & & & $x$ & & & & & & & \\
\hline Callopistes bicuspidatus Chani, 1976 & & & & & $x$ & & & & & & & \\
\hline Colubridae indet. & & & & & $x$ & & & & & & & \\
\hline aff. Bothrops Wagler, 1824 & & & & & $x$ & & & & & & & \\
\hline Boa $s p$. & & & & & $x$ & & & & & & & \\
\hline \multicolumn{13}{|l|}{ Class Aves } \\
\hline \multicolumn{13}{|l|}{ Order Anseriformes } \\
\hline Anas platalea Vieillot, 1816 & & & & & & & & $x$ & & $x$ & & \\
\hline Anas $s p$. & & & & & & & & & $x$ & & & \\
\hline Chloephaga sp. 1 & & & & & & & & $x$ & & & & \\
\hline Chloephaga sp. 2 & & & & & & & & $x$ & & & & \\
\hline Dendrocygna $s p$. & & & & & & & & & & $x$ & & \\
\hline Dendrocygninae indet. & & & & & $x$ & & & & & & & \\
\hline Anatidae indet. & & & & & & & & & & $x$ & & \\
\hline Order Tinamiformes & & & & & & & & & & & & \\
\hline
\end{tabular}




\begin{tabular}{|c|c|c|c|c|c|c|c|c|c|c|c|c|}
\hline \multirow[t]{2}{*}{ Taxa } & \multicolumn{12}{|c|}{ Localities } \\
\hline & $C S$ & BSar & $C V$ & CRS & $F M H$ & $L O$ & Bals & BSJ & $P L F$ & $C S D$ & $G d R$ & $P d B$ \\
\hline Nothura parvula Tambussi, 1989 & & & & & $x$ & & & & & & & \\
\hline Nothura darwini Gray, 1840 & & & & & & & & $x$ & & $x$ & & \\
\hline Eudromia cf. E. elegans Geoffroy St. Hillaire, 1832 & & & & & $x$ & & & & & & & \\
\hline Eudromia olsoni Tambussi and Tonni, 1985 & & & & & $x$ & & & & & & & \\
\hline Tinamidae indet. & & & & & & & & & & $x$ & & \\
\hline \multicolumn{13}{|l|}{ Order Rheiformes } \\
\hline Heterorhea dabbenei Rovereto, 1914 & & & & & $x$ & & & & & & & \\
\hline Hinasuri nehuensis Tambussi, 1995 & & & & & $x$ & & & & & & & \\
\hline Rhea americana (Linné, 1758) & & & & & & & & & $x$ & & & \\
\hline Rhea $s p$. & & & & & & & & $x$ & & $x$ & & \\
\hline \multicolumn{13}{|l|}{ Order Ralliformes } \\
\hline Mesembriornis milneedwardsi Moreno, 1889 & & & & & $x$ & & & & & & & \\
\hline Chunga incerta Tonni, 1974 & & & & & $x$ & & & & & & & \\
\hline \multicolumn{13}{|l|}{ Order Gruiformes } \\
\hline Porphyrio sp. & & & & & & & & $x$ & & & & \\
\hline \multicolumn{13}{|l|}{ Order Ciconiiformes } \\
\hline Vultur gryphus Linné, 1758 & & & & & $x$ & & & & & & & \\
\hline Dryornis pampeanus Moreno and Mercerat, 1891 & & & & & $x$ & & & & & & & \\
\hline
\end{tabular}

Order Passeriformes

Pseudoseisura-Pseudoseisuropsis $\quad X$

Motacillinae indet.

Class Mammalia

Order Didelphimorphia

Thylatheridium pascuali Reig, 1958

$X$

Thylamys contrerasi Mones, 1980

Thylamys pusillus (Desmarest, 1804)

Thylophorops aff. T. perplana Ameghino, 1904

Lutreolina tracheia Rovereto, 1914

Lutreolina biforata Rovereto, 1914

Hyperdidelphys inexpectata Ameghino, 1889

Hyperdidelphys parvula Rovereto, 1914

Sparassocynus bahiai Mercerat, 1899

Lestodelphys halli (Thomas, 1921)

Lestodelphys $s p$.

Order Sparassodonta

Notocynus hermosicus Mercerat, 1891

Achlysictis lelongi Ameghino, 1891

Borhyaenidium $s p$.

Order Polydolopimorphia

Argyrolagus palmeri Ameghino, 1904

Microtragulus argentinus Ameghino, 1904 


\begin{tabular}{llllllllllllllll}
\hline \hline Taxa & \multicolumn{11}{c}{ Localities } \\
\hline & CS & BSar & CV & CRS & FMH & LO & BalS & BSJ & PLF & CSD & GdR & PdB \\
\hline
\end{tabular}

Order Cingulata

Euphractini sp. "a" nov. Scillato-Yané, 1982

Holozaedyus laevisculptus Rovereto, 1914

Zaedyus pichiy (Desmarest, 1804)

Chaetophractus villosus (Desmarest, 1804)

Tolypeutes matacus (Desmarest, 1804)

Tolypeutes sp. nov. (Scillato Yané in Deschamps, 2005)

Macrochorobates chapalmalensis Scillato-Yané 1980

Macrochorobates $s p$.

Chorobates villosissimus (Rovereto, 1914)

Chorobates rescens (Ameghino, 1887)

Chorobates $s p$.

\section{$x$}

$x$

Macroeuphractus retusus Ameghino, 1887

Macroeuphractus cf. M. morenoi (Lydekker, 1894)

Propraopus $s p$.

Eutatus seguini Gervais, 1867

"Eutatus" praepampaeus Ameghino, 1904

Doellotatus inornatus (Rovereto, 1914)

Doellotatus cf. D. praecursor (Rovereto, 1914)

Doellotatus chapadmalensis Bordas, 1933

Ringueletia simpsoni (Bordas, 1933)

Chasicotatus cf. C. peiranoi Esteban and Nasif, 1996

Plaina cf. P. intermedia (Ameghino, 1888)

Pampatherium $s p$.

Eosclerocalyptus lineatus Ameghino, 1888

Sclerocalyptus ornatus (Owen, 1845)

$x$

Neosclerocalyptus $s p$.

Berthawyleria $s p$.

Aspidocalyptus sp.

Trachycalyptus sp. nov. Scillato-Yané et al., 1995

Panochthus tuberculatus (Owen, 1839)

Panochthus $s p$.

$x$

$\begin{array}{llll}x & x & x & \\ x & x & x & x\end{array}$

$X$

$x$
$x \quad x$
$x$

$x$

$X$

$x \quad x$

$x$

$X$

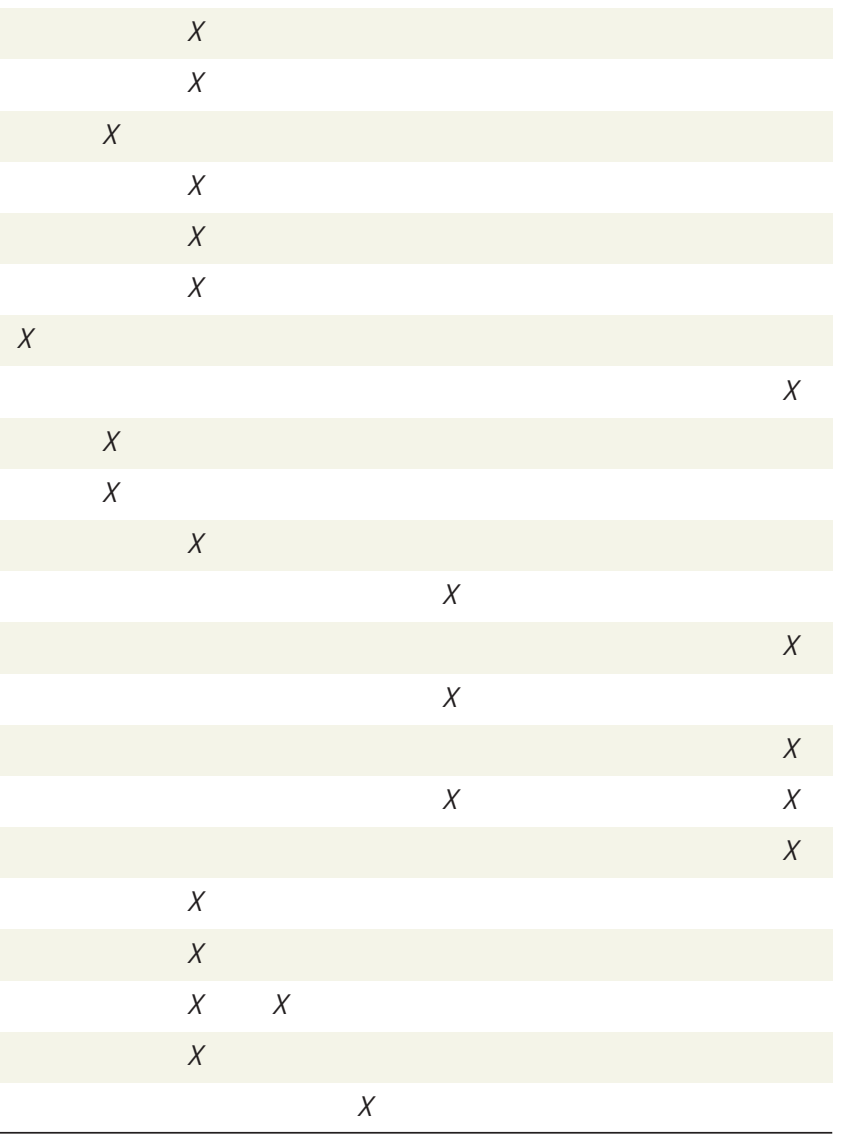




\begin{tabular}{|c|c|c|c|c|c|c|c|c|c|c|c|c|}
\hline \multirow[t]{2}{*}{ Taxa } & \multicolumn{12}{|c|}{ Localities } \\
\hline & $C S$ & BSar & $C V$ & CRS & $F M H$ & LO & Bals & BSJ & PLF & CSD & $G d R$ & $P d B$ \\
\hline Phlyctaenopyga trouessarti (Moreno, 1888) & & & & & $x$ & & & & & & & \\
\hline Eleutherocercus antiquus (Ameghino, 1887) & & & & & $x$ & & & & & & & \\
\hline Palaeodaedicurus antiquus Ameghino, 1889 & & & & & $x$ & & & & & & & \\
\hline \multicolumn{13}{|l|}{ Order Tardigrada } \\
\hline Proscelidodon patrius Ameghino, 1889 & & & & & $x$ & & & & & & & \\
\hline Scelidotherium leptocephalum Owen, 1839 & & & & & & & & $x$ & & $x$ & & $x$ \\
\hline Scelidotherium cf. S. tarijense Gervais and Ameghino, 1880 & & & & & & & & & & & & $x$ \\
\hline Glossotherium sp. & & & & & & & $x$ & $x$ & & & & $x$ \\
\hline Lestodon armatus Gervais, 1855 & & & & & & & & $x$ & & & & $x$ \\
\hline Lestodon $s p$. & & & & & $x$ & & & & & & & \\
\hline Megatherium americanum Cuvier, 1796 & & & $x$ & & & & $x$ & & & & & \\
\hline Myrmecophaga caroloameghinoi Kraglievich, 1934 & & & & & $x$ & & & & & & & \\
\hline
\end{tabular}

Order Rodentia

Phtoramys C.P. hidalguense Pascual, Pisano and Ortega, $1965 \quad x$

$x$

Phtoramys homogenidens Ameghino, 1887

aff. Neophanomys biplicatus Rovereto, 1914

Neophanomys $s p$.

Pithanotomys columnaris Ameghino, 1887

Pithanotomys macer Ameghino, 1888

Pseudoplataeomys formosus Kraglievich, 1934

Eucelophorus cabrerai Kraglievich, 1927

Xenodontomys ellipticus Kraglievich, 1927

Actenomys priscus (Owen, 1840)

Eumysops laeviplicatus Ameghino, 1888

Eumysops formosus Ameghino, 1906

Ctenomys talarum Thomas, 1898

Ctenomys $s p$.

Ctenomys kraglievichi (Rusconi, 1930)

Myocastor columnaris Rusconi, 1929

Paramyocastor diligens (Ameghino, 1888)

Lagostomus incisus (Ameghino, 1888)

Lagostomus $s p$.

Lagostomus maximus (Desmarest, 1817)

Palaeocavia $s p$.

Neocavia depressidens Parodi and Kraglievich, 1948

Neocavia $s p$.

Dolicavia $s p$

Galea $s p$.

Microcavia $s p$

Cavia aperea Erxleben, 1777

Orthomyctera sp.

$x \quad x$

$x$

$x$

$X$

$x$

$x$

$X$

$x$

$x \quad x \quad x$

$\begin{array}{ll}x & x \\ x & \\ x\end{array}$

$X$

$\begin{array}{ll}x & x \\ x\end{array}$




\begin{tabular}{|c|c|c|c|c|c|c|c|c|c|c|c|c|}
\hline \multirow[t]{2}{*}{ Taxa } & \multicolumn{12}{|c|}{ Localities } \\
\hline & $C S$ & BSar & $C V$ & CRS & $F M H$ & $\angle O$ & Bals & BSJ & PLF & $C S D$ & $G d R$ & $P d B$ \\
\hline Prodolichotis $s p$. & & & & & $x$ & & & & & & & \\
\hline Caviodon australis (Ameghino, 1888) & & & & & $x$ & & & & & & & \\
\hline Cardiomys sp. & & & & & $x$ & & & & & & & \\
\hline Phugatherium cataclisticum Ameghino, 1889 & & & & & $x$ & & & & & & & \\
\hline Neochoerus cf. N. tarijensis (Ameghino, 1902) & & & & & & & & $x$ & & & & $x$ \\
\hline Telicomys giganteus Ameghino, 1904 & & & & & $x$ & & & & & & & \\
\hline Phyllotini gen. et sp. nov. Bond et al., 1998 & & & & & $x$ & & & & & & & \\
\hline Necromys bonapartei (Reig, 1978) & & & & & $x$ & & & & & & & \\
\hline Auliscomys formosus Reig, 1978 & & & & & $x$ & & & & & & & \\
\hline Reithrodon auritus (Fischer, 1814) & & & & & $x$ & & & $x$ & & $x$ & & \\
\hline Lundomys sp. & & & & & & & & $x$ & & & & \\
\hline Holochilus brasiliensis (Desmarest, 1819) & & & & & & & & & & $x$ & & \\
\hline Akodon azarae (Fischer, 1829) & & & & & & & & $x$ & & & & \\
\hline Akodon iniscatus Thomas, 1919 & & & & & & & & $x$ & & & & \\
\hline Oxymycterus $s p$. & & & & & & & & $x$ & & & & \\
\hline Calomys laucha (Fischer, 1814) - C. musculinus (Thomas, 1913) & & & & & & & & & & $x$ & & \\
\hline Phyllotis $s p$. & & & & & & & & $x$ & & & & \\
\hline \multicolumn{13}{|l|}{ Order Lagomorpha } \\
\hline Lepus europaeus Linné, 1758 & & & & & & & $x$ & & & & & \\
\hline \multicolumn{13}{|l|}{ Order Notoungulata } \\
\hline Paedotherium bonaerense Ameghino, 1887 & & $x$ & & & $x$ & & $x$ & & & & & \\
\hline Paedotherium typicum Ameghino, 1887 & & & & & $x$ & & & & & & & \\
\hline Paedotherium cf.P. minor Cabrera, 1937 & $x$ & & & $x$ & & & & & & & & \\
\hline Paedotherium $s p$. & & & $x$ & & & & & & & & & \\
\hline Tremacyllus impressus Ameghino, 1888 & $x$ & & & & $x$ & & & & & & & \\
\hline Tremacyllus $c f . T$. impressus & & & & $x$ & & & & & & & & \\
\hline \multicolumn{13}{|l|}{ Hemihegetotherium $s p$. } \\
\hline Pseudotypotherium sp. & & & & & $x$ & $x$ & & & & & & \\
\hline Toxodon chapalmalensis Ameghino, 1908 & & & & & $x$ & & & & & & & \\
\hline Toxodon platensis Owen, 1837 & & & $x$ & & & & $x$ & & & & & \\
\hline Alitoxodon vetustum Rovereto, 1914 & & & & & $x$ & & & & & & & \\
\hline Trigodon gaudryi Ameghino, 1882 & & & & & $x$ & & & & & & & \\
\hline Trigodon minor Rovereto, 1914 & & & & & $x$ & & & & & & & \\
\hline Xotodon prominens Ameghino, 1889 & & & & & $x$ & & & & & & & \\
\hline Xotodon ambrosetti Rovereto, 1914 & & & & & $x$ & & & & & & & \\
\hline Xotodon $s p$. & & & & & $x$ & & & & & & & \\
\hline \multicolumn{13}{|l|}{ Order Litopterna } \\
\hline Eoauchenia primitiva Ameghino, 1887 & & & & & $x$ & & & & & & & \\
\hline Epitherium laternarium Ameghino, 1888 & & & & & $x$ & $x$ & & & & & & \\
\hline Diplasiotherium robustum Rovereto, 1914 & & & & & $x$ & & & & & & & \\
\hline Promacrauchenia antiqua Ameghino, 1889 & & & & & $x$ & & & & & & & \\
\hline
\end{tabular}




\begin{tabular}{|c|c|c|c|c|c|c|c|c|c|c|c|c|}
\hline \multirow[t]{2}{*}{ Taxa } & \multicolumn{12}{|c|}{ Localities } \\
\hline & $C S$ & BSar & $\mathrm{CV}$ & CRS & FMH & LO & Bals & BSJ & PLF & CSD & $G d R$ & $P d B$ \\
\hline Promacrauchenia kraglievichi Parodi, 1931 & & & & & $x$ & & & & & & & \\
\hline Promacrauchenia $s p$. & & & & $x$ & & & & & & & & \\
\hline Macraucheniopsis ensenadensis (Ameghino, 1888) & & & & & & & & $x$ & & & & \\
\hline Macrauchenia patachonica Owen, 1838 & & & & & & & & & & $x$ & & $x$ \\
\hline \multicolumn{13}{|l|}{ Order Proboscidea } \\
\hline Notiomastodon platensis (Ameghino, 1888) & & & & & & & & & & & & $x$ \\
\hline Gomphotheriidae indet. & & & & & & & & $x$ & & & & \\
\hline \multicolumn{13}{|l|}{ Order Artiodactyla } \\
\hline Tayassuinae indet. & & & & & & & & $x$ & & & & \\
\hline Lama sp. & & & & & & & & $x$ & & & & \\
\hline Lama guanicoe (Müller, 1776) & & & & & & & $x$ & & & $x$ & $x$ & \\
\hline Ozotoceros bezoarticus (Linné, 1758) & & & & & & & & & $x$ & $x$ & & \\
\hline Morenelaphus bonaerense Carette, 1922 & & & & & & & & & & & & $x$ \\
\hline Ovis aries Linné, 1758 & & & & & & & & & $x$ & $x$ & & \\
\hline Bos taurus Linné, 1758 & & & & & & & & & $x$ & $x$ & & \\
\hline \multicolumn{13}{|l|}{ Order Perissodactyla } \\
\hline Equus (Amerhippus) neogaeus Lund, 1840 & & & & & & & & & & $x$ & & $x$ \\
\hline Hippidion principale (Lund, 1846) & & & & & & & & $x$ & & & & \\
\hline Hippidion $s p$. & & & & & & & & & & & & $x$ \\
\hline \multicolumn{13}{|l|}{ Order Carnivora } \\
\hline Parahyaenodon argentinus Ameghino, 1904 & & & & & $x$ & & & & & & & \\
\hline Tetraprothomo argentinus Ameghino, 1908 & & & & & $x$ & & & & & & & \\
\hline Cyonasua clausa Ameghino, 1904 & & & & & $x$ & & & & & & & \\
\hline Smilodon populator Lund, 1842 & & & & & & & & & & & & $x$ \\
\hline Pseudalopex $s p$. & & & & & & & & $x$ & & & & \\
\hline Pseudalopex gymnocercus (Fischer, 1814) & & & & & & & & & & $x$ & & \\
\hline cf. Herpailurus & & & & & & & & $x$ & & & & \\
\hline
\end{tabular}

BalS, Balneario Saldungaray; BSar, Barrancas de Sarmiento; BSJ, Bajo San José; CSD, Chacra Santo Domingo; CRS, Cantera Relleno Sanitario; CS, Cantera Seminario; CV, Cantera Vialidad; FMH, Farola Monte Hermoso; GDR, García del Río; LO, Las Oscuras; PdB, Playa del Barco; PLF, Puesto La Florida. 